\title{
Arabic and its Alternatives: Language and Religion in the Ottoman Empire and its Successor States
}

\author{
Heleen Murre-van den Berg
}

\section{1 \\ Introduction $^{1}$}

When in the mid-eighties I entered the field of Semitic Studies via the study of Hebrew and Aramaic, "Classical Syriac" was one of the obligatory courses of the program. Through the careful study of grammar and a variety of texts these classes took me into the world of the Syriac churches. It was to take me some years to start getting the bigger picture of their histories and contemporary situation, but one thing I accepted as a given from the earliest stages of my studies: that there was an undeniable link between the "Syriac" language and the "Syriac" churches. This message was conveyed by the texts we read, by the convenient subdivision into "East" and "West" Syriac scripts and "East" and "West" Syrian Churches, ${ }^{2}$ and by the references made by the contemporary churches (which at that period were settling in Europe, including the Netherlands) to Syriac as 'their' language. This conceptual link was further strengthened by the fact that for the closely related Aramaic languages used by other religious communities ("Jewish," "Samaritan," "Mandaic"), different scripts were used and separate literatures had emerged. ${ }^{3}$

1 I thank the many colleagues who read and commented on earlier versions of this paper, first and foremost Lucas van Rompay, the co-editors of this volume, and the other contributors. Outside this circle, Matthias Kappler and Stelios Irakleous from the field of Karamanli studies have added their critical advice. I also thank the anonymous reviewer who kindly provided a number of critical suggestions for further improvement. All remaining faults and misperceptions of course are entirely my own.

2 Note that at the time "Syrian" rather than "Syriac" was the usual term; in Dutch ("Syrisch") no distinction can be made between "Syriac" as referring to the language and "Syrian" referring to cultural, ethnic and/or national aspects. The adjective "Syrian" was used referring to Syriac Orthodox and Syrian Arab Republic matters, until in April 200o, the church officially allowed its name to be translated in English as Syriac Orthodox Church (Syriac Orthodox Resources http://sor.cua.edu/SOCNews/200o/00040301.html; last seen 26/11/2017).

3 On the history of Aramaic and related literatures, see Holger Gzella, A Cultural History of Aramaic: From the Beginnings to the Advent of Islam (Leiden: Brill, 2015); on Arabic, Hebrew, Mandaic and Aramaic, see Stefan Weninger (ed.), The Semitic Languages: An International 
That this exclusive link between Syriac churches and the Classical Syriac language in the modern and contemporary period is as much a matter of ideology as of practice, I began to realize when I started a specialization in socalled Modern or Neo-Aramaic, the variety used by the (East Syriac) Assyrian Christians of Urmia in Iran. Whereas most linguists prefer to emphasize the connection of these modern languages to the wider Aramaic language group, Syriac Christians usually prefer the term Sureth/Surait ("Syriac") for both the Classical and the Modern language - thereby conceptualizing the modern language form as firmly part of their Syriac heritage. Linguistically, however, the boundaries between the 'Syriac' of the Syriac churches and other Aramaic languages and cultures were much fuzzier than I had previously assumed. The most important realization, however, came when I engaged with Arabic as part of the Christian heritage of the Middle East. I learnt that when in the early twentieth century the Syriac churches put a strong emphasis on the importance, and hence preservation, of their "Syriac heritage," 4 in fact most of the writings about this heritage were in Arabic rather than in Syriac. Thus, while Syriac was shaped more and more into the most important common identifier of Syriac Christianity, Syriac Christians were making use of a variety of other languages in religious as well as secular contexts. Alongside a host of languages including English, French, German, Persian, Turkish and Kurdish (to name a few), it was Arabic that prevailed in most of the Syriac communities. ${ }^{5}$

The question is, therefore: if Arabic was in actual practice as important as Syriac, despite all the attention the latter receives in ecclesial as well as secular circles, what would explain this gap between language ideology and language practice? And, if indeed there is a gap between ideology and practice, is it the same for all Syriac churches? Further, do we find a similar divergence between ideology and practice in other Middle-Eastern communities? And how is this related to the role Syriac and Arabic play as religious, ritual, languages? And what has all of this to do with the rise of new Middle-Eastern nationalisms in which language and language reform play crucial roles: Turkish, Arab, Iranian, Armenian, Assyrian and Zionist? And, finally: what does the case of Arabic in

Handbook (Berlin: De Gruyter Mouton, 2011), in particular John F. Healey, "34. Syriac," 637652, and Françoise Briquel Chatonnet, "35. Syriac as the Language of Eastern Christianity," $65^{2-659 .}$

4 Sebastian P. Brock, Aaron M. Butts, George A. Kiraz, Lucas Van Rompay, Gorgias Encyclopedic Dictionary of the Syriac Heritage (Piscataway, NJ: Gorgias Press, 2011).

5 Heleen Murre-van den Berg, "Classical Syriac and the Syriac Churches: A Twentieth-Century History," in Syriac Encounters: Papers from the Sixth North American Syriac Symposium, Duke University, 26-29June 2011, ed. M. Doerfler, E. Fiano, K. Smith (Peeters: Louvain, 2015), 119-148. 
the Middle East tell us about persisting but varied and varying connections between language, religion, and communal identities more generally?

It is this cluster of questions that formed the impetus to a comparative project that was financed by the Dutch Research Council nwo, under the title "Arabic and its Alternatives: Religious Minorities in the Formative Years of the Modern Middle East (1920-1950)." In September 2013, the group organized its first conference under the title "Common Ground: Changing Interpretations of Public Space in the Middle East among Jews, Christians and Muslims in the 19th and 2oth Centuries," the proceedings of which were recently published. ${ }^{6}$ During this conference as well as in the ensuing volume, the language issue was contextualized within larger questions of changing ideologies and practices of public space. It addressed the ways in which language (in schools, journalism, and publishing) as much as other cultural practices (dress, urbanization, the resettlement of WWI-refugees, funeral practices, religious processions, music) in the period following WWI was used simultaneously to include some and exclude other non-Muslims in the newly emerging public sphere of the Mandate and early independent states. It is the changing interpretations of the so-called millet system under the influence of modernization, secularization, and competing nationalisms, as well as the contextualized concept of the term 'minority' as it developed in the twentieth century, that underlie the discussions in the present volume. ${ }^{7}$ In June 2016, the research group organized a second conference in Leiden and The Hague, this time zooming in on the issue of language, with a slight variation on the title of the program as a whole: "Arabic and its Alternatives: Religious minorities and their languages in the emerging nation states of the Middle East (1920-1950)." In this volume most of the contributions of the 2016 conference are collected, complemented with relevant essays by the conference organizers that were not presented during the conference.

6 S.R. Goldstein-Sabbah, H.L. Murre-van den Berg (eds.), Modernity, Minority, and the Public Sphere:Jews and Christians in the Middle East (Leiden: Brill, 2016).

7 Heleen Murre-van den Berg, "Searching for Common Ground: Jews and Christians in the Modern Middle East," in Goldstein-Sabbah, Modernity, Minority, and the Public Sphere, 3-38. On the introduction and subsequent changes of the term 'minority' in the Middle Eastern context, see especially Benjamin Thomas White, The Emergence of Minorities in the Middle East: The Politics of Community in French Mandate Syria (Edinburgh: Edinburgh University Press, 2011), and Saba Mahmood, Religious Difference in a Secular Age: A Minority Report (Princeton/Oxford: Princeton University Press, 2016); for a discussion of the structural connection to the ideals of Enlightenment, secularism, and modernity, see Aamir R. Mufti, "Secularism and Minority: Elements of a Critique," Social Text 45 (1995): 75-96. 
The first impetus to the project and this volume came from the observable gap between language ideology and language practice, the second came from the equally observable ambiguous role of Arabic in the formation of Arabic nationalism in the early twentieth century. On the one hand, 'Arabic' is posited by most nationalist authors as the one undisputed element of 'Arab identity,' to be preferred over and above fuzzy or potentially exclusive concepts such as Arab 'ethnicity' or 'race,' Islam as the quintessential 'Arab' religion, or that of a primordial 'Arab nation.' Indeed, the linguistic approach promised to bridge the societal and regional cleavages that the new nationalism intended to heal, especially those of religion and religious denomination. ${ }^{8}$ On the other hand, however, 'Arabic' is a much less clear category than nationalists and historians tend to assume. Not only is there an ongoing debate on what kind of Arabic could function as the language of the Arab nation (especially the question where on the continuum between the highly formalized classical and the barely standardized local colloquial forms it is situated), but also whether indeed 'Arabic' is the one and only parameter of Arabness: do all who speak Arabic consider themselves Arabs, and can everyone who speaks and writes Arabic be considered part of the Arab nation? ${ }^{9}$ As will become clear in this volume, these questions were not settled in the early decades of the twentieth century nor in the heydays of nationalism in the 1950s and 1960s. If indeed, as I posited, the inclusion of non-Muslims was one of the primary motives behind the creation of this particular concept of Arabness and Arab nationalism,

8 So, e.g., George Antonius (The Arab Awakening: The Story of the Arab National Movement, London: Hamish Hamilton, 1938) and Edmond Rabbath (Unité Syrienne et devenir arabe, Paris: Marcel Rivière, 1937) who wrote in English and French, respectively, but also authors like Fu'ad al-Khatib who is discussed by Peter Wien in this volume. Albert Hourani (Arabic Thought in the Liberal Age, 1798-1939, Cambridge, CUP, 1983/2014; 1st ed. Oxford 1962) similarly takes his starting point in the language. Adeed Dawisha (Arab Nationalism in the Twentieth Century: From Triumph to Despair, Princeton: Princeton University Press, 2003, esp. 13-15) has a more political approach, taking 'Arabic' as a starting point for 'Arabism,' but pan-Arabic political unity as the driving force of 'Arab nationalism.' See also Rashid Khalidi et al., The Origins of Arab Nationalism (New York: Columbia University Press, 1991), on Iraq, see Peter Wien, Iraqi Arab Nationalism: Authoritarian, Totalitarian, and pro-fascist Inclinations, 19321941 (Abingdon/New York: Routledge, 2006).

9 Kees Versteegh, The Arabic Language (Edinburgh: Edinburgh University press 1997/2014), Reem Bassiouney, Arabic Sociolinguistics: Topics in Diglossia, Gender, Identity, and Politics (Washington DC: Georgetown University Press, 2009), Clive Holes, Modern Arabic: Structures, Functions, and Varieties, Rev. Ed. (Washington D.C.: Georgetown University Press, 2004), and Reem Bassiouney, Language and Identity in Modern Egypt (Edinburgh, UK: Edinburgh University Press, 2014), Ziad Fahmy, Ordinary Egyptians: Creating the Modern Nation Through Popular Culture (Stanford, CA: Stanford University Press, 2011). 
understanding non-Muslim involvement in Arabic may give us important insight into non-Muslims' relationship with the newly emerging Arab states.

\section{Language, Religion and Communal Identities}

As stated above, it has been one of the major aims of the project underlying this book to better understand the role of the non-Muslim communities in the development of the modern Arab states, both in their important contributions to these states and in the ongoing uncertainties about whether they are actually fully participating citizens, or whether implicit and explicit forms of exclusion continue to be at work. One of the major difficulties in studying these complicated and varied patterns of inclusion and exclusion, of assimilation and isolation, is that depending on sources and starting points it is either inclusivist or exclusivist interpretations that dominate. When the focus is on identity formation and diaspora politics, Christians' and Jews' separation from the rest of the population will come to the fore. However, if we concentrate on modern secular literature in Arabic, Christian and Jewish authors come across as full participants in the Arabic public space. The basic assumption of the project has been that a study of language ideologies and practices might provide a way to include inclusivist and exclusivist perspectives within one and the same conceptual framework, with language ideology and practice as reliable indicators of the varied and sometimes conflicting ways in which non-Muslims relate to societies that by and large are dominated by Muslims. ${ }^{10}$ Our goal with this approach is to bring these different perspectives into one study. Therefore, the starting point is Arabic, which is then contrasted with a variety of other languages that play a role in these communities - i.e., starting from the potential communalities to see where these are complemented and contradicted by exclusivist practices. Put differently: in this approach the crucial importance of language for all kinds of identity formation processes is accepted, with as a necessary corollary the assumption that multilingualism in individuals and groups may indicate patterns of multiple identification that not necessarily exclude each other.1 ${ }^{11}$ At the same time, by taking our analytic

10 For an introduction into matters of language ideology, see Kathryn A. Woolard \& Bambi B. Schieffelin, "Language Ideology," Annu.Rev.Anthropol. 23 (1994): 55-82. For the connections between language ideologies and concepts of modernity and group identity, see Richard Bauman, Charles L. Briggs, Voices of Modernity: Language Ideologies and the Politics of Inequality (Cambridge: Cambridge University Press, 2003).

11 Rogers Brubaker, Frederick Cooper, "Beyond 'Identity," Theory and Society 29 (2000): 1-47. On language, see Jennifer Dickinson, "Languages for the Market, the Nation, or the 
starting point in what in the socio-political and legal parlance of most Middle Eastern states is referred to as "religious communities," we assume that religious identification continues to be of importance - but how exactly, is one of the main questions of this essay and this volume.

Two authors need a brief introduction here, because their work has been crucial in developing the themes of the project. The first of these is Yasir Suleiman, whose numerous publications on the role of Arabic in Arab nationalism proved important for the project, in particular The Arabic Language and National Identity (2003). ${ }^{12}$ Though in the historiography of Arab nationalism there is an overall tendency to take the role of Arabic in nationalist ideology for granted, Suleiman convincingly unpacks this seemingly straightforward connection. He discusses the early identification between Arabic and Islam, the way Jewish and Christian contributions to Arabic literature were perceived in the mediaeval and pre-modern period, and how their contributions were viewed by the twentieth-century nationalists who often considered themselves the true guardians of the Arabic language. He also describes how in the modern period most nationalists saw Arabic as the defining factor of Arab nationalism, the "unified and unifying language" in Sati' al-Husrî's terms. ${ }^{13}$ Finally, he addresses the tension between regional Arabism and pan-Arabism, often but certainly not always linked to tensions between local varieties of Arabic and the modernized, standardized and interregional fuṣha or "purified" language usually called Standard Arabic (SA) by linguists. As Suleiman notes in the introduction, his work is mostly on language ideology, much less on language practice.

Margins: Overlapping Ideologies of Language and Identity in Zakarpattia," Int.L. J. Soc. Lang 201 (2010): 53-78.

12 Other relevant works include Yasir Suleiman, "Charting the Nation: Arabic and the Politics of Identity," Annual Review of Applied Linguistics (2006) 26: 125-148, Suleiman, A War of Worlds: Language and Conflict in the Middle East (Cambridge: Cambridge University Press, 2004) and Suleiman, Arabic in the Fray: Language Ideology and Cultural Politics (Edinburgh: Edinburgh University Press, 2013). He mostly addresses contexts in which SA is put up against other forms of Arabic, in the Arabic world in the wider sense, from the early twentieth c. onwards; in addition he discusses the language situation in contemporary Israel/Palestine, with SA up against Hebrew.

13 Suleiman, The Arabic Language, 143; see also Heleen Murre-van den Berg, "The Language of the Nation: The Rise of Arabic among Jews and Christians (1900-1950)," British Journal of Middle Eastern Studies 43(2) (2016): 176-190. 
This is different in the seminal work by Sheldon Pollock(2006), The Language of the Gods in the World of Men: Sanskrit, Culture, and Power in Premodern India. This work describes in much detail how in the Indian subcontinent, mostly in the early second millennium, an impressive vernacularization process took off in which Sanskrit became wedded to cultural cosmopolitan imagination alongside more localized vernacular literatures and imaginations. For Pollock, much more so than for Suleiman, religion is an important factor to take into account, although in fact one of Pollock's main conclusions is that in the vernacularization processes at the beginning of the second millennium religion played less of a role than generally is assumed, with courts and political power being much more important than religion and religious leadership. It is exactly the complex power dynamics between religious 'sacred' languages that tend to secularize and standardize on the one hand, and vernacular languages that undergo literization (creating a written language) and literarization (developing a corpus of texts, 'literature') on the other, that is so important for pre-modern India. However, understanding these processes will also contribute to a better understanding of the developments in the early modern and modern Middle East. The parallels, however, are not straightforward, especially because religion and religious culture play a fundamentally different role in the Middle East than in the cultural-linguistic dynamics in India. We will return to the role of religion below, but for now it is important to note Pollock's differentiation between vernacular, localized and 'national' impetuses on the one hand, and the cosmopolitan, 'civilizational', impetuses on the other. These two processes, which often take place at the same time and the same place, influencing each other, sometimes as rivals, sometimes as allies, constitute the fundamental framework of this volume. As Pollock sees it, these developments often concern long-term processes that started long before the modern period. Our case of the twentieth-century Arab states, therefore, needs the perspective of the longue durée, if only of the Ottoman period that preceded it.

Finally, taking Pollock as a starting point also means that the theme of modernity in relation to the themes of this volume are put in a somewhat different light. Pollock's study of linguistic developments in the pre-modern Indian subcontinent convincingly shows that issues of vernacularization and cosmopolitanism, standardization and hybridization, conservatism and modernization, are part and parcel of historical dynamics over long periods of time. These dynamics in and of themselves, in language as much as in other cultural ideologies and practices, are nothing new. What is new, though, is the way in which some aspects of these ideologies and practices not only contributed significantly to the modernizing practices of the late nineteenth and early 
twentieth centuries, but were also constitutive of what modernity came to be. If anything, a very specific type of language ideology and practice is one of the constitutive forces without which our modern world, predicated on ideas about ethnic and national groups, would look very different.

The same is true for 'religion,' another of these concepts that in some of its ideas and practices has been among humans from their earliest history, but which in the form encountered in this volume is shaped by the modern world as much as it constitutes a formative part of it, on a par with language and ethnicity. ${ }^{14}$ With this volume we hope to contribute to the ongoing discussion about the relationship between the two concepts of religion and language, and their relationship with identity formation, or, borrowing Brubaker's term, the creation and maintenance of "groupness." Earlier work, such as that of Omoniyi and Fishman, Joseph and Myhill, tends to see rather straightforward connections, in which language is a fairly automatic corollary to 'ethnicity' and is then, together with religion, easily put to work in undergirding 'national' identities. However important these links are and whatever precursors of such links between language, religion and nation/ethnic group can be recognized, taking the broader view of the Middle East starting from the Ottoman Empire provides so many exceptions to this one-to-one rule that as a heuristic device it obscures rather than enlightens. In fact, such theories tend towards an anachronistic approach in which current or historical ideologies of links between language, religion and community are taken as a given, and which then looks backwards for proof of their pre-existence, thereby excluding other options from the analysis. ${ }^{15}$

Conversely, the historical context is mostly excluded from Wein and Hary's sociolinguistic "religiolect." This concept underlines the importance of religious boundaries for the description of varieties of language. However, when looking at language varieties from the perspective of religious boundaries one

14 Charles Taylor, A Secular Age (Cambridge: Harvard University Press, 2007); Theodore Vial, Modern Religion, Modern Race (Oxford, oup, 2016), Bauman and Briggs: Voices of Modernity. For a discussion of both the parallels and differences between 'religion' and 'language' in identity formation and nation building see Rogers Brubaker, Grounds for Difference (Cambridge MA: Harvard University Press, 2015) and Adrian Hastings, The Construction of Nationhood: Ethnicity, Religion and Nationalism (Cambridge: Cambridge University Press, 1997).

15 John Earl Joseph, Language and Identity: National, Ethnic, Religious (Houndmills/ New York: Palgrave Macmillan, 2004), John Myhill, Language, Religion and National Identity in Europe and the Middle East (Amsterdam: John Benjamins, 2006), Tope Omoniyi, Joshua A. Fishman, eds, Explorations in the Sociology of Language and Religion (Amsterdam, John Benjamins, 2006). 
easily overlooks not only the historical dynamics that change the meaning of certain distinctive linguistic or orthographic traits within the religious group, but also the ongoing exchange with the larger linguistic context outside the group under discussion. ${ }^{16}$ One of the underlying issues that Wein and Hary's important essay brings to the fore, however, is the fact that linguists have been trained to connect language to 'ethnic' or 'national' groups, taking such groups as the starting point for their analysis. This presents scholars of languages primarily located within religious groups with the problem of how to describe these groups, especially in the case of religious groups with strong distinct communal identities based not only on religion but also on language (and less on geography). It is here that an integral look at the linguistic developments in the Ottoman Empire and its successor states, from the perspective of mostly non-Muslim sub-groups, can add significantly to our thinking about a very fundamental aspect of how communal identities are formed and changed over time.

Starting from the basic question of how non-Muslim communities in the Middle East used language to re-define their position in the newly emerging Arab states between 1920 and 1950, we will in this introduction, based on a wide range of studies in this burgeoning field, first look back at processes of language change in the Ottoman period, especially at a number of important instances of the literization and literarization of a vernacular language (in short: vernacularization), while also paying attention to what at first sight looks like its opposite, i.e., the cases in which non-Muslims chose to write in the majority languages of the time, mostly Turkish and Arabic (cosmopolitanization). Our focus will then move to the first half of the twentieth century, when processes of ongoing vernacularization were complemented and counteracted by cosmopolitan practices, be it by greatly extending the use of Arabic or by the increased use of French and English. The final section offers a first attempt at analysing these developments in view of long-term vernacular versus cosmopolitan trends, and their typically modern expressions in rivalling nationalisms and new forms of cosmopolitanism. Not unexpectedly, religion is an important component in all of these trends.

16 Benjamin Hary, Martin J. Wein, "Religiolinguistics: On Jewish-, Christian- and Muslim-defined Languages," International Journal of the Sociology of Language (2013) 220: $85^{-108 .}$ 
A superficial look at the linguistic situation in the Middle East seems to confirm that rather than local vernacularizations it is the dominance of a few languages with a strong literary tradition, religious or otherwise, that set the standard. Unlike Europe, where in the early modern and modern periods a fair array of local languages, from Portuguese to Danish, from Dutch to Italian, became the standardized languages of national communities, in the Middle East only three languages acquired a similar status combining literary, scholarly and political usages: Arabic, Persian and (Ottoman) Turkish. In terms of Pollock's categories these three are better described as religious, literary or administrative cosmopolitan languages turning imperial, rather than as vernacular languages turning 'national.'

However, a closer look at the linguistic developments in the Ottoman and Persian Empires quickly shows that the Middle Eastern situation is in fact not so different from that in Europe. As Michiel Leezenberg, also taking his starting point in Pollock's framework, has argued earlier, a great many "vernacular moments" can be identified, some of which have been extensively described, others less so. ${ }^{17}$ Quite a few of these earlier vernacularization processes, while mostly starting as religious innovations, became wedded to fully-fledged nationalist movements, which in turn resulted in the creation of separate states with separate languages in the nineteenth and twentieth centuries. This is true for the modern forms of Greek, Romanian, Serbian, Bulgarian and Armenian, all of which have their origins in the seventeenth to early nineteenth centuries. In all of these cases, a new written language was developed alongside the classical language in which the bulk of religious and scholarly literature had been written, and which in most cases still functions as a liturgical language until today. In some cases, the classical languages were modernized and simplified with an eye towards the vernacular (Greek Katharevousa, Armenian Grabar). Over time, however, these forms lost their position to the new and purified vernaculars in which the script and orthographic standards of the classical forms were used. In other contexts the modern vernaculars provided the starting point of renewal, for instance standardized forms of Modern Aramaic among Jews and Christians in Hebrew and Syriac script, and Kurdish modelled along Persian lines in 'Arabic' script. Because the seventeenth and eighteenth centuries were periods of increasingly frequent exchanges between Europe

17 Michiel Leezenberg, "The Vernacular Revolution: Reclaiming Early Modern Grammatical Traditions in the Ottoman Empire," History of Humanities (2016) 1,2: 251-275; and Leezenberg in this volume. 
(including Russia) and the Ottoman Empire, with diplomats, merchants and missionaries interacting intensively with religious and secular leadership, especially Christian leaders, it has often been suggested that Western contacts were the primary cause of these vernacular developments. However, their wide regional spread, also in areas where foreigners were hardly present, as well as the use of mostly indigenous models for literization and literarization, suggests that western inspiration can only have been one factor among many.

A notable example of such a vernacular process under mostly local incentives concerns Kurdish, the main topic of Leezenberg's contribution in this volume. He describes three distinct moments of Kurdish vernacularization in the early modern period. The process started in the fifteenth and sixteenth centuries at the Erdelan court in Senneh/Sanandaj, current-day Iran. The local Hawrami (or Gorani as it is termed in the West) koine was put into writing and used for learned poetry, alongside Persian, which remained the language of administration. In the late seventeenth and early eighteenth centuries, Northern Kurmanji was put into writing in the Diyarbakir and Hakkari regions, with a wider (though still mostly religious) range of texts, which besides poetry included history and grammar. Around 180o, the Central Sulaymaniyah dialect (Sorani Kurdish) was put into writing, again with a focus on local religious learning, and with little that foreshadowed its later central position in North Iraq. ${ }^{18}$

Although there is no proof of mutual influence, the patterns of Kurdish vernacularization resemble those that we see in two Aramaic-speaking communities in the Kurdish area. In Zakho and Nerwa, two small cities in the Northwestern part of what today is Iraqi Kurdistan, from the sixteenth century onwards texts were produced in a literary language based on the local Northeastern Neo-Aramaic vernacular, the spoken language of the Jewish communities of the region. In the same script that was used for Hebrew texts, local rabbis wrote Aramaic translations of the Bible (reminiscent of, but different from the earlier Targumim) as well as midrashic commentaries on the Bible. ${ }^{19}$ These are precisely the genres that, while cherishing the Hebrew literary and religious heritage, also in earlier periods of Jewish history made use of

18 See also Michiel Leezenberg, "Eli Teremaxi and the Vernacularization of Medrese Learning in Kurdistan," Iranian Studies 47 (2014): 713-733.

19 The most important texts of this early have been edited and translated by Yona Sabar (The Five Scrolls in Jewish Neo-Aramaic Translations: Dialects of Amidya, Dihok, and Urmiya. A Critical Edition Based on Recordings and Manuscripts, Comparisons with Old Aramaic Bible Translations, Commentaries and Midrashim ('Ēāh w-lāšon: Jerusalem, Magnus Press, 2006), and Jewish Neo-Aramaic Translations of Hebrew Liturgical Poems: A Critical Edition ( $\bar{E} d \bar{a} h$ w-lāšon: Jerusalem, Magnus Press, 2009)); for a general overview of Jewish 
vernacular forms of Aramaic in order to make this heritage accessible to lay people who did not know Hebrew.

A similar vernacularization process was started on the basis of a close cognate of Jewish Northeastern Neo-Aramaic, the Aramaic vernacular of the Christian communities in the Hakkari region and the northern Mesopotamian plains also known as 'Modern Syriac' or Sureth. These Ottoman texts in Christian Neo-Aramaic originated not far from the centres of Jewish learning, in the provincial towns of Alqosh and Telkepe. The oldest surviving manuscripts date from the late seventeenth and early eighteenth centuries, but their scribes explicitly date the origins of the Neo-Aramaic texts to about one century earlier. This small corpus consists mostly of religious poetry attributed to individual poets (different from much of the medieval anonymous liturgical hymns), who recount stories from the Bible and from the Syriac hagiographic and narrative tradition in a standardized form of the vernacular Aramaic. These texts were studied extensively by Alessandro Mengozzi, who shows that rather than aiming to expand or even supplant the Classical Syriac Christian heritage and learning, its authors intended to introduce, explicate and transmit it. In addition to poetry, some remnants of biblical commentary and a few fragments of grammar have survived. ${ }^{20}$

As in the Kurdish case, where Persian and Arabic maintained much of the functions they had before, Classical Syriac remained important in the domains in which it was used before priests started to write the vernacular: in the colophons of manuscripts, in formal letters, in new hymns for the liturgy, and in the amulet texts that protected against all kinds of evil. Thus, the functions of the newly written vernacular remained fairly limited compared to those of the classical language. It was only in nineteenth-century Urmia (Persia) that

Neo-Aramaic in their wider context, see Geoffrey Khan, "40, Northeastern Neo-Aramaic," in The Semitic Languages, ed. Weninger, 708-724.

20 Alessandro Mengozzi, Israel of Alqosh and Joseph of Telkepe. A Story in a Truthful Language, Religious Poems in Vernacular Syriac (North Iraq, 17th century) (CsCO 589-590, Scr. Syr. 230-231; Louvain: Peeters 2002), and Religious Poetry in Vernacular Syriac from Northern Iraq (17th-2oth Centuries): An Anthology, Introduction and Translation (csco 627-628 / Scr. Syr. 240-241; Louvain: Peeters 2011). See further Heleen Murre-van den Berg, Scribes and Scriptures: The Church of the East in the Eastern Ottoman Provinces (1500-1850) (Louvain: Peeters, 2015). Printing in Classical Syriac was mostly done outside the Middle East or in Maronite circles in Lebanon, see J.F. Coakley, The Typography of Syriac: A Historical Catalogue of Printing Types, 1537-1958 (New Castle, DE: Oak Knoll Press, 2006) and Coakley, "Printing in Syriac, 1539-1985 / Drucken in Syrisch, 1539-1985," in Eva Hanebutt-Benz, Dagmar Glass, Geoffrey Roper, Sprachen des Nahen Ostens und die Druckrevolution: Eine interkulturelle Begegnung / Middle Eastern Languages and the Print Revolution: A Cross-cultural Encounter (Westhofen: WVA-Verlag Skulima, 2002), 93-116. 
a fully-fledged modern literary language was developed. With the support of Protestant and later also Catholic missionaries, this modernized and standardized form of the vernacular served not only the religious and educational aims of the missionaries, but also the emerging "Syrian" (later "Assyrian") ethnonational community as a whole. ${ }^{21}$

Among the Armenians, vernacularization processes started in the eighteenth but did not catch on until the nineteenth century. Already in the seventeenth and eighteenth centuries, both the Western and Eastern vernaculars were described and literized to some extent, in the west by the founder of the Armenian-Catholic Mekhitarist Order (est. Constantinople, 1701), Mekhitar (Mxit'ar) of Sebaste (Sivas). His Grammar of Western Armenian was published in Venice in 1727. The Eastern vernacular was first described by the German scholar Iohann Ioachim Schroeder in 1711. However, the central position of the modernized Classical Armenian Grabar remained uncontested, and both the Mekhitarists, in their aim to elevate people, and clergy and Eastern Armenian authors in Eastern Anatolia and Russia preferred Classical Armenian for their publications. In the nineteenth century, however, both the Western and Eastern vernaculars were literarized. Religious and secular publications were printed within the Ottoman, Persian and Russian empires, but also further away, in Venice (Arsēn Aytěnean) and Smyrna, in what was to be called Ashkharhabar, the "civil language."22

21 Heleen Murre-van den Berg, From a Spoken to a Written Language: The Introduction and Development of Literary Urmia Aramaic in the Nineteenth Century (De Goeje Fund XXviII, Leiden, 1999); Adam Becker, Revival and Awakening: Christian Mission, Orientalism, and the American Evangelical Roots of Assyrian Nationalism (1834-1906) (Chicago: Chicago University Press, 2015). A similar movement did not emerge among the Syriac Orthodox of Eastern Anatolia, but there was some interest in printing, see Ahmet Taşğın and Robert Langer, "The Establishment of the Syrian Orthodox Patriarchate Press," in Historical Aspects of Printing and Publishing in Languages of the Middle East. Papers from the Third Symposium on the History of Printing and Publishing in the Languages and Countries of the Middle East, University of Leipzig, September 2008, edited by Geoffrey Roper (Leiden/ Boston: Brill 2014), 181-192.

22 Méline Pehlivanian, "Mesrops Erben: die Armenischen Buchdrucker der Frühzeit / Mesrop's Heir's: The early Armenian Book Printers," in Hanebutt-Benz et al., Sprachen des Nahen Ostens und die Druckrevolution, 53-92, Marc Nichanian, Ages et usages de la langue arménienne (Geneva: Éditions Entente, 1989); Agop Hacikyan, Gabriel Basmajian, Edward S. Franchuk, Nourhan Ouzounian, eds, The heritage of Armenian literature. Vol. 3: From the Eighteenth Century to Modern Times (Detroit: Wayne State University Press, 2005), Jasmin Dum-Tragut, Armenian: Modern Eastern Armenian (Amsterdam: John Benjamins Publishing Co, 2009), J.F. Coakley, "Printing in the Mission Field," Harvard Library Bulletin 9.1 (1998): 5-34, Barbara J. Merguerian, "The ABCFM press and the development of the Western Armenian language," Harvard Library Bulletin 9.1 (1998): 35-49. 
The wedding of the literarized Bulgarian (South Slavonic) language to the emerging nationalist movement in the nineteenth century is the last example from within the Ottoman Empire. ${ }^{23}$ Like Kurdish and Aramaic, vernacular Bulgarian saw an initial phase of literarization starting in the seventeenth century. After that, "religious edifying literature" started to be published, collectively referred to as "the damascenes" after Damaskinos Studites, the Greek author of a text collection (Thesauros) that was translated into New Bulgarian in the early seventeenth century. These and later translations of other religious texts had their origins in monastic circles, with monks in the centre of the movement, focusing on the "religious and didactic message." ${ }^{24}$ This was also the case in a curious contribution from the mid-eighteenth century by the Athonite monk Paisij Hilendarsky. His proto-nationalist historical work, based on Bulgarian sources available in the monasteries, does not seem to have found much resonance at the time, and although it was printed in 1844 the book (in a mixed language closer to Church Slavonic than to vernacular Bulgarian) had little impact on the so-called Bulgarian Renaissance that was to follow in the nineteenth century. During this "Renaissance" anti-Greek nationalist themes and aims were connected to standardization and literarization of the modern language. Only then did Modern Bulgarian develop into a truly supra-regional standardized literary language. ${ }^{25}$

\section{Imperial Languages among Non-Muslims}

So far, all these examples represent cases in which literized vernaculars of specific communities (mostly but not exclusively non-Muslim) succeeded in gaining ground vis-à-vis the classical (liturgical) language in that same community. In some instances the newly literized vernacular replaced the classical language for scholarly and religious communication, but more often the existing religious functions of the classical language remained intact while the vernacular was used to expand the literary and scholarly genres within that community, usually starting in the field of religion with new types of hymns, saints' lives, Bible translations and catechisms. In a subsequent stage, mostly in

23 Roger Gyllin, The Genesis of the Modern Bulgarian Literary Language (Ph.D. Uppsala University: Stockholm 1991), Denis Vovchenko, Containing Balkan Nationalism: Imperial Russia and Ottoman Christians, 1856-1914 (Oxford: Oxford University Press, 2016). According to Gyllin, "codification" and "standardization" in grammars did not take place until the 19th c. $\left(25^{-7}\right)$.

24 Gyllin, The Genesis, 46-69, esp. 60-1.

25 Gyllin, The Genesis, 69-103. 
the second half of the nineteenth century, the new language was used to create a secular literature, including novels as well as scholarly and political texts, translations of Western originals as well as original texts in these vernaculars. However, despite the dominance of this pattern in a number of Christian and Jewish communities, it was not the only pattern available. As important in accommodating the needs of modernizing Jewish and Christian communities was the ongoing adoption and adaptation of the most important literary and political languages of the region, that is, Turkish and Arabic. ${ }^{26}$

Although Christian literature in Arabic is most relevant to the discussion of the use of Arabic in the twentieth century, we should also pay attention to the various literatures in Ottoman Turkish. At least four non-Muslim communities are known to have produced Turkish texts, texts which only recently have started to receive proper scholarly attention. ${ }^{27}$ This is especially true for the Turkish texts produced in the "Rum" or "Greek" Orthodox communities of Anatolia and Istanbul. This text corpus is usually called "Karamanlidika," referring to the original centre of this community in the Karaman region in Southern Anatolia. The term Karamanlidika came to refer especially to the defining characteristic of this corpus, i.e., these Turkish texts are written in Greek rather than in Ottoman (Arabic-based) script. ${ }^{28}$ Though the bulk of these texts

26 A similar cause could be made for the use of Persian by Jews and Christians in the Iranian world; the literature on this phenomenon is more limited, perhaps because of the relatively small communities. See Vera Moreen In Queen Esther's Garden: An Anthology of Judeo-Persian Literature (New Haven/London: Yale University Press, 200o), esp. 9-21.

27 For a general overview of these literatures (except for Syro-Turkish), see Johann Strauss, "Who Read What in the Ottoman Empire (19th-2oth Centuries)?," Arabic Middle Eastern Literatures 6,1 (2003), 39-76, and three recently edited volumes: Evangelia Balta, Mehmet Ölmez, eds, Between Religion and Language: Turkish-Speaking Christians, Jews, and Greek-Speaking Muslims and Catholics in the Ottoman Empire (Istanbul: Eren, 2011), Evangelia Balta with Mehmet Ölmez, Cultural Encounters in the Turkish-Speaking Communities of the Late Ottoman Empire (the IsIs Press Istanbul, 2014), and Evangelia Balta, Matthias Kappler, eds, Cries and Whispers in Karamanlidika Books: Proceedings of the First International Conference on Karamanlidika Studies (Nicosia, 11th-13th September 2008) (Wiesbaden: Harrassowitz Verlag, Wiesbaden, 2010). Some of its earliest students included members of the Assumptionists in Istanbul and Athens, see Stavros Th. Anestides, "The Centre for Asia Minor Studies and Books Printed in Karamanli. A Contribution to the Compilation and the Bibliography of a Significant Literature," Balta \& Kappler, Cries and Whispers, 147-153 and Johann Strauss, "Is Karamanli Literature Part of a 'Christian-Turkish (Turco-Christian) Literature'?," Balta \& Kappler, Cries and Whispers, 152-200, here 160; they refer to the work of the Fathers Séverien Salaville, Eustace Louis (Louis Corn) and Eugène Daleggio (Athens).

28 On this discussion, see Matthias Kappler, "Transcription Text, Regraphization, Variety? Reflections on 'Karamanlidika," in Éva Á. Csató, Astrid Menz, Fikret Turan, Spoken Ottoman in Mediator Texts (Wiesbaden: Harrassowitz, 2016), 119-128. 
were published and printed in the nineteenth century, the origins of the corpus go back to the eighteenth century. The texts often resulted from the efforts of a few intrepid priests or monks intending to elevate their flocks. ${ }^{29}$ In the nineteenth century, the emerging rivalry with and opposition to the upcoming Hellenization (Pan-Hellenic) movement gave further impetus to the use of an additional, non-Greek, language. ${ }^{30}$ Already in its earliest phase grammatical studies played an important role. ${ }^{31}$

The same had happened in the Anatolian Armenian and Anatolian Syriac Orthodox communities. Many of these Christians were Turkish-speaking, perhaps partly because in earlier periods some Turkish speakers had converted to Christianity and retained their language, partly because for a variety of socio-economic and cultural reasons Christians of Anatolia had adopted the Turkish lingua franca of the region. The Syro-Turkish corpus is fairly small and dates mostly to the second half of the nineteenth century, when some Syriac Christians began to adopt Turkish in their communities. Most important are the journals that were published towards the end of the nineteenth century. ${ }^{32}$ The Armeno-Turkish corpus is larger, with precursors in the seventeenth and eighteenth centuries. Here too, the bulk of publications date from the nineteenth century, including a number of prominent journals. American Protestant missionaries played an important role in publishing

29 For earlier examples in Anatolia, see Anna Ballian, "Karamanli Patronage in the Eighteenth and Nineteenth Centuries: the Case of the Village of Germir/Kermira," Balta \& Kappler, Cries and Whispers, $45^{-62}$, as well as various articles on the activities of the eighteenthcentury priest Serapheim Pissidios, Ioannis Theocharides, "Unexploited Sources on Serapheim Pissidio," Balta \& Kappler, Cries and Whispers, 125-134.

30 For an extensive overview, see Strauss, "Is Karamanli Literature ...?," 152-200; for the nineteenth-century nationalization and standardization in opposition to Greek, see Sia Anagnostopoulou, "Greek Diplomatic Authorities in Anatolia," in Balta \& Kappler, Cries and Whispers $63^{-78}$ and Şehnaz Şişmanoğ-lu Şimşek, "The Anatoli Newspaper and the Heyday of the Karamanli Press," in Balta \& Kappler, Cries and Whispers, 109-123.

31 Matthias Kappler, "The Place of the Grammatiki Tis Tourkikis Glossis (1730) by Kaneloos Spanós in Ottoman Greek Grammarianism and its Importance for Karamanlidika Studies," in Balta \& Ölmez, Cultural Encounters, 105-117.

32 Benjamin Trigona-Harany, "Syro-Ottoman: a description of Ottoman Turkish in Syriac Letters," in Balta, Ölmez (eds.), Between Religion and Language (2011), 15-41; Benjamin Trigona-Harany, "A Bibliography of Süryânî Periodicals in Ottoman Turkish," Hugoye: Journal of Syriac Studies 12.2 (2009): 287-300. Note that Turkish had been used by Syriac Christians in the Mongol period, in Persia and Central Asia, see Pier Giorgio Borbone, "Syroturcica 1: The Önggüds and the Syriac Language," in Malphono w-Rabo d-Malphone. Studies in Honor of Sebastian P. Brock, edited by George A. Kiraz (Piscataway, NY 2008) and Borbone, "Syroturcica 2: The Priest Särgis in the White Pagoda," Monumenta Serica $56,1(2008): 487-503$. 
such texts, especially in Istanbul, where Turkish was the dominant language among Armenians. ${ }^{33}$

The Jewish community of Istanbul, while retaining the use of Spanish-based Ladino that reflected their origins in the Iberian Peninsula, Turkish had become the first or second language of a large part of the community. In the seventeenth century, Turkish had been written in Hebrew letters, most notably in a translation of the Bible produced in Constantinople, although this may represent an isolated work commissioned in the context of a learned circle of mostly Dutch and British scholars. ${ }^{34}$ Again, the nineteenth century became the period in which the number of such publications increased considerably. ${ }^{35}$

Therefore the terms Greco-Turkish or Karamanlidika, Armeno-Turkish and Syro-Turkish refer to the use of a specific communal script familiar to the religious group that is using it, not to a specific form of the language in grammati$\mathrm{cal}$, syntactical or semantic terms. At the same time, however, the ongoing study of these various corpora indicates that there are indeed significant differences between the linguistic characteristics of these texts and those of the Ottoman Turkish corpus in general. ${ }^{36}$ Some of these differences concern the semantic field of the vocabulary (biblical and liturgical terminology), whereas in other cases there is grammatical influence from the texts that were translated (i.e., in translations of the Greek/Hebrew Bible). More important for the topic of this introduction is the fact that a number of Greco-Turkish texts display elements of a more vernacular, local Anatolian form of Turkish vis-à-vis the standardized Ottoman Turkish. Usually these belong to the older strata of the corpus. In general, it seems that the texts written in communal scripts, especially the more formal or literary, often were closer to the standardized Ottoman Turkish and to each other than the different scripts would suggest. Thus, whereas some texts from these corpora when transcribed into the standard Ottoman, Arabic-based script would be difficult to understand for a cosmopolitan reader of Ottoman Turkish, the bulk would be readable - in some cases easily so. In fact, it has been suggested that nineteenth-century Armeno-Turkish novels,

33 Masayuki Ueno, "One script, two languages: Garabed Panosian and his Armeno-Turkish newspapers in the nineteenth-century Ottoman Empire," Middle Eastern Studies 52:4 (2016): 605-622; Benjamin Trigona-Harany, The Ottoman Süryânî from 1908 to 1914 (Piscataway NJ: Gorgias Press, 2009), Hacikyan, The Heritage of Armenian literature, vol. 3, 58-6o.

34 Hannah Neudecker, The Turkish Bible Translation by Yahya bin 'Ishak, also called Haki (1659) (Leiden: Het Oosters Instituut 4, 1994). The primary commissioner was the wellknown Johannes Amos Comenius from Bohemia who in the 1650 -6os was active in Amsterdam.

35 J.P. Cohen, Becoming Ottomans: Sephardi Jews and Imperial Citizenship in the Modern Era (Oxford: Oxford University Press, 2014), 26-30.

36 Strauss, "Is Karamanli Literature ...?," 190-194. 
among which translations of Western novels, stimulated non-Armenians to learn the Armenian script in order to be able to read them. ${ }^{37}$

In all four of these groups, the use of Turkish in communal script became less popular in the late nineteenth century. At that time, Ottoman ideologies expressly aimed at including non-Muslims as full citizens of the Ottoman state encouraged Jews and Christians to fully participate in the literary production of the state. This made the Arabo-Ottoman script a logical choice over and above the communal alphabets, especially for texts that were not specifically religious. This practice reached its culmination in the early days of the Young Turks, when after the revolution of 1908 the ideal of Ottoman citizenship encouraged the creation of publishing houses and journals in which a modernized form of Ottoman Turkish was used. However, this brief period came to an end when in the years leading up to the First World War the Young Turks increasingly advocated an ethnicized and Islamicized Turkification, rather than the earlier inclusive 'Ottomanization.' Soon this was followed by accusations of treason and disloyalty to the state directed at many who were considered nonTurk and non-Muslim, especially the Armenians. During the war, Armenians and other Christians in the Turkish-speaking regions became suspect and suffered various degrees of massacre, rape and expulsion. For the Rum Orthodox Christians the culmination came during the League of Nations-supervised population exchange of 1923, when they were expelled en masse to Greece. Thus, by 1924, when the Ottoman state was abolished and replaced by the Turkish Republic, most of Anatolia was purged of its Christian population. The non-Muslim Turkish-speakers that survived usually ended up in environments in which they were forced quickly to learn other languages: mostly Arabic for those in the emerging Arab states, and Armenian and Greek for those in Soviet Armenia (alongside Russian) and Greece. The few Jewish and Christian Turkish speakers that remained in Turkey adapted quickly to the newly modernized Turkish language with its Latin alphabet, thus relinquishing their Ottoman heritage, as did most Turks of the time. At the same time, the classical religious languages in their traditional forms were cherished and taught in churches and synagogues as much as was possible under Turkish governmental control. ${ }^{38}$

\footnotetext{
37 Strauss, "Who Read What," 53-55.

38 Whereas the Armenian and Syriac genocides and the Greek-Turkish population exchange of 1923 have generated a considerable amount of research, the history of the non-Muslim communities in the Turkish state has so far been underresearched. For the Armenians, see Bahar Rumelili and Fuat Keyman, "Enacting multi-layered citizenship: Turkey's Armenians' struggle for justice and equality," Citizenship Studies 20,1 (2016): 67-83, for the Syriac-Orthodox see Naures Atto, Hostages in the Homeland, Orphans in the Diaspora: Identity Discourses Among the Assyrian/Syriac Diaspora (Leiden: Leiden University Press, 2011).
} 
The developments in the Arab provinces of the Ottoman Empire were similar to those in the Turkish-speaking regions. In the regions where Arabic was the dominant religious, cultural and administrative language, Jews and Christians had for many centuries participated in the language of the majority by writing, copying and later publishing books in it. Here, too, significant parts of this literature were written in communal scripts: Hebrew for Judeo-Arabic, Syriac for Syro-Arabic (usually called Garshuni, also spelled Karshuni). The two largest groups of Christians, however, i.e., the Rum Christians of the patriarchates of Jerusalem and Antioch and the Copts of Egypt, who wrote all or most of their new texts in Arabic, had from an early stage used the Arabic alphabet for their Arabic texts. This was not for want of a suitable communal script: the Greek and Coptic scripts continued to be used for the (mostly liturgical) texts in those languages.

The different linguistic practices among the Rum Orthodox Christians of the Levant may be explained, at least to some degree, from the early date at which they adopted Arabic as their primary spoken and literary language: probably in the late seventh or eighth century, soon after the Muslim conquests. The fact that there were already Christian Arabic-speaking groups before the rise of Islam helped Arabic to quickly gain ground among the Christians of the Levant, for cultural as much as socio-political reasons. ${ }^{39}$ This enabled the upper layers of the Christian communities to participate in the emerging Arabic culture of the Omayyad and Abbasid courts, with Christians in the roles of political advisors, personal physicians, and prominent scholars of science, philosophy and translation. Scholars have used the term "Christian Arabic" to characterize the particular form of Arabic of these writings, because it tends to deviate from the stated norm of Quranic Classical Arabic used in Muslim texts. ${ }^{40}$ When texts written by Jews are included as well these types in 'substandard' Arabic are often styled "Middle Arabic," as opposed to "Classical Arabic."41 As Khan notes, "Middle" here refers to its position on a continuum between "Classical"

39 On the origins of Arabic Christianity and its relation to Syriac Christianity, see Sidney Griffith, "What does Mecca have to do with Urhōy? Syriac Christianity, Islamic Origins, and the Qurān," in Syriac Encounters: Papers from the Sixth North American Syriac Symposium, Duke University, 26-29 June 2011, edited by M. Doerfler, E. Fiano, K. Smith (Peeters: Louvain, 2015), 369-99.

40 The basic source for Christian Arabic texts continues to be Georg Graf, Geschichte der christlichen arabischen Literatur (Vatican City: Biblioteca Apostolica Vaticana, 1944-1951); the most recent bibliographical update is found in Herman Teule and Vic Schepens, "A Thematic Christian Arabic Bibliography, 1940-1989," Journal of Eastern Christian Studies (2015) 67-1/2, 143-224. On Judeo-Arabic, see Benjamin Hary, "Judeo-Arabic in its Sociolinguistic Setting," Israel Oriental Studies 15 (1995): 129-155. Geoffrey Khan, “47. Middle Arabic," in Weninger, The Semitic Languages, 817-835. 
and "vernacular," not to a certain period of time between the "Classical" and the "Modern" period. Just as important, the use of this "middle" form was not restricted to non-Muslims. Even though Islamic texts generally tended to conform to the classical norm more strictly than the average Christian or Jewish text would, Muslim authors occasionally also employed a more vernacular register. As with Christians and Jews, this choice depended on genre and intended audience as much as on the writing skills of the author. ${ }^{42}$ Unlike Turkish written by Christians and Jews, many Middle Arabic texts were written in the Arabic script, especially in the Rum Orthodox and Coptic communities. While most of these texts were written primarily for internal audiences, more than was the case with Turkish, Christian Arabic writing became part of Arabic literature, creating a 'Republic of Letters' that was not confined to co-religionists, but open to all who could read and write Arabic. ${ }^{43}$

The other way around, Rum Christians in the Arab provinces of the Ottoman Empire were increasingly described as "Arab Christians," with Arabic being seen as more important than Greek. This was further stimulated by Russian Orthodox support for Rum Christians; they too favoured Arabic over Greek in their educational programs. ${ }^{44}$ We will return to the Greek-Arabic struggles in the next section, but here it is important to note that many of the Rum Orthodox clergy had already adopted Arabic for parts of the liturgy in an earlier phase. The use of Arabic was furthered by Catholic missionaries, even

42 Jacques Grand'Henry, "Christian Middle Arabic," in: Encyclopedia of Arabic Language and Linguistics, edited by Lutz Edzard, Rudolf de Jong; J. Lentin \& J. Grand'Henry, Moyen arabe et variétés mixtes de l'arabe à travers l'histoire (Peeters, Louvain-la-Neuve, 2008), Holes, Modern Arabic, 36-50; Kees Versteegh, "Religion as a Linguistic Variable in Christian Greek, Latin, and Arabic," in Nora S. Eggen and Rana Issa, Philologists in the World: A Festschrift in Honour of Gunvor Mejdell (Oslo: Novus Press, 2017), 57-88.

43 Muhsin J. al-Musawi, The Medieval Islamic Republic of Letters: Arabic Knowledge Construction (Notre Dame, Indiana: University of Notre Dame Press, 2015).

44 Denis Vovchenko, "Creating Arab Nationalism? Russia and Greece in Ottoman Syria and Palestine (1840-1909)," Middle Eastern Studies 49 (2013): 901-918, Elena Astafieva, "Imaginäre und wirkliche Präsenz Rußlands im Nahen Osten in der zweiten Hälfte des 19. Jahrhunderts (avec résumé français)," in Europäer in der Levante - Zwischen Politik, Wissenschaft und Religion (19.-20. Jahrhundert) / Des Européens au Levant - Entre politique, science et religion (XIX $-X X^{e}$ siècles), edited by Dominique Trimbur (München: R. Oldenbourg Verlag, 2004), 161-186. On the Russian impact on Palestine, see earlier literature including Derek Hopwood, The Russian Presence in Syria and Palestine, 1843-1914: Church and Politics in the Near East (New York: Oxford University Press, 1969) and Walter Zander, Israel and the Holy Places of Christendom (London: Weidenfeld and Nicholson: 1971). 
more so when printing of these liturgies became possible. ${ }^{45}$ While much printing of the earlier days was done in Rome or Vienna, some churches established their own Arabic presses, the Maronites in Quzhayya (Lebanon) in 1610, the Rum Christians in Aleppo in 1706, and ash-Shuwayr (Lebanon) in 1733. These presses published a wide range of religious literature. ${ }^{46}$ In the nineteenth century, authors such as Butrus al-Bustani (who was closely connected to the Protestant mission in Beirut) contributed to the further development of Arabic literature, which included all kinds of new scholarly, scientific, political and literary genres, as part of the movement that now commonly is called the Nahda.47 Though Levantine Christians of various denominations played important roles in these early phases of the Nahda, these Christian authors self-consciously inscribed themselves in an already existing secularizing movement of authors from all religious and political backgrounds who sought to emancipate Arabic from its classical heritage, and transform it into a modern language of literature, science and politics. ${ }^{48}$ And indeed, politics was an important part of it, because it also became an instrument of the emancipation of the 'Arabic' provinces vis-à-vis the Ottoman centre, providing Arab nationalists of the early

45 Constantin A. Panchenko, Arab Orthodox Christians under the Ottomans: 1516-1831 (Jordanville NY: Holy Trinity Seminary Press, 2016; tr. Russian, Moscow 2012), Carsten Walbiner, "Monastic Reading and Learning in Eighteenth-Century Bilad al-Sham: Some Evidence from the Monastery of Al-Shawayr (Mount Lebanon)," Arabica 6,4 (2004): 462-77, and Bruce Masters, Christians and Jews in the Ottoman Arab World: The Roots of Sectarianism (Cambridge: CUP, 2001); it is not always clear whether manuscripts and printed books with Arabic translations of the liturgy testify to existing practices, or should be seen as attempts to change current practices initiated by local clergy or church hierarchies, sometimes in the context of Catholic missions.

46 Geoffrey Roper, "Early Arabic Printing in Europe / Arabischer Frühdruck in Europa," in Hanebutt-Benz et al., Sprachen des Nahen Ostens und die Druckrevolution, 129-150 and Dagmar Glass \& Geoffrey Roper, "Arabischer Buch- und Zeitungsdruck in der Arabischen Welt / Arabic Book and Newspaper Printing in the Arab World," idem, 177-226.

47 Ussama Makdisi, Artillery of Heaven: American Missionaries and the Failed Conversion of the Middle East (Ithaca: Cornell University Press, 2008), Geoffrey Roper, "The beginnings of Arabic printing by the ABCFM, 1822-1841," Harvard Library Bulletin 9.1 (1998): 50-68. On the nahda, see also Rana Issa, "The Arabic Language and Syro-Lebanese National Identity: Searching in Buțrus al-Bustānīs Muhịt al-Muhịț," Journal of Semitic Studies LXII/2 (2017): 465-484, and Butrus Abu-Manneh, "The Christians between Ottomanism and Syrian Nationalism: The Ideas of Butrus Al-Bustani," Int. J. Middle East Stud. II (1980): 287-304.

48 See especially the work of Stephen Sheehi, Foundations of Modern Arab Identity (Gainesville: University Press of Florida, 2004), "Towards a Critical Epistemology of the Nahda," Journal of Arabic Literature 43 (2012): 269-298 and "Butrus al-Bustani's Nafir Suriya and the National Subject as Effect," in Butrus al-Bustani: Spirit of the Age, edited by Adel Beshara (Melbourne: Phoenix Publishing 2014), 275-309. 
twentieth century with a convenient tool not only for communication, but also with an instrument to forge an 'Arab' people out of the ethnic, regional and religious diversity of these Arab provinces. ${ }^{49}$

Compared to the Levantine Rum and Maronite Christians, the (East) Syriac Christians of the Church of the East, the (West) Syriac Orthodox Church, and their respective Catholic offshoots the Chaldean Church and the Syriac Catholic Church, went through a somewhat different development. In the Middle Ages, in both the East and West Syriac Church, Arabic was an important language although it never completely replaced Classical Syriac. The ongoing significance of Syriac also showed in the popularity that Syro-Arabic or Garshuni (which co-existed with texts transmitted in Arabic script) enjoyed in both churches. The major upheavals of the fourteenth century, however, considerably reduced the geographical spread of the Syriac churches. The Church of the East was hit particularly hard, especially in Arabic- and Persian-speaking areas. Early in the fifteenth century its remaining dioceses were found mostly in the Kurdish region, with modest communities in the plains surrounding it, roughly corresponding to the eastern Ottoman provinces Diyarbakir, Van and Mosul and Northwestern Persian Azerbaijan. In most of these remaining dioceses, a modern vernacular of Aramaic (the Neo-Syriac or Neo-Aramaic mentioned above) was used. Speakers of Arabic were found mostly in the Mosul area. For the Syriac Orthodox the number of Arabic speakers was slightly higher, with more substantial communities remaining in the heartland of today's Syria, in and near cities such as Homs, Damascus and Aleppo. In parts of southeastern Turkey, in and around the city of Mardin, Arabic was also still spoken. Although Classical Syriac was the main language of writing, Arabic continued to be used, mostly in Garshuni forms..$^{50}$

In the Ottoman period Arabic started to gain ground. Alongside the first attempts to write the vernacular Aramaic (as discussed above), it was Arabic that became the most important language of religious and cultural innovation, mostly in connection with the Catholic movement. Especially among the Church of the East, Arabic speakers were the first to be interested in contacts with the Catholic Church. As with all Catholic movements among Middle Eastern Christians various factors were at play, such as the wish to establish contacts with the wider Christian world in the Middle East and beyond, the wish to modernize religion by taking inspiration from other Christian

49 Dagmar Glaß, "48. Creating a Modern Standard Language from Medieval Tradition: The Nahda and the Arabic Academies," in Weninger, The Semitic Languages, 835-844.

$5^{\circ}$ Murre-van den Berg, Scribes and Scriptures. On Garshuni, see George Kiraz, Túrāṣ mamllā; A Grammar of the Syriac Language (Piscataway NJ: Gorgias Press, 2012), 291-322. 
traditions, and the wish to acquire political and economic allies in a world in which the downsides of Ottoman rule, which tended to favour Muslims, could be mitigated by the interventions of Western consuls and foreign missionaries. Arabic served these aims well and there is a fairly strong correlation between the groups that over the centuries converted to Catholicism, and those that used Arabic as their primary language of speaking and writing. ${ }^{51}$

All over the Arab-speaking Middle East, the vast majority of Jewish communities over the centuries had adopted Arabic as their mother tongue and as an important written language. While Hebrew and Aramaic continued to be used for specific religious purposes, and while at the boundaries of the Arab world other vernaculars were in use (Aramaic in Kurdistan, Berber in North-Africa), most Jewish communities lived in urban environments in which Arabic was the norm. Thus, the cover term "Judeo-Arabic" for Arabic in Hebrew (Rashi) script refers to a linguistic practice that comes in different shapes and forms, depending on where in the Arab world it originated. On the whole, however, it differs from Classical Arabic in the same way as Christian Arabic does, and therefore is usually defined as "Middle Arabic," distinct from "Classical Arabic" in vocabulary and semantics, in grammar and in orthography. Depending on local developments Judeo-Arabic texts display more or less influence from local Arabic vernaculars, vernaculars that in many places were somewhat different from the Arabic vernaculars of their Muslim and Christian neighbours. Unlike what happened in the Christian communities, however, it seems that the first wave of communal and linguistic modernization in the seventeenth and eighteenth centuries did not lead to a further standardization and printing of the written Arabic of the Jews in the Middle East. The difference between Jews and Christians in this respect became even more pronounced when in the nineteenth century organizations such as the France-based Alliance Israélite, and later also the Great Britain-based Anglo-Jewish Association, started to invest heavily in Jewish education in the Middle East. Their main emphasis was on French, alongside Hebrew, with English becoming more important in the twentieth century. Rather than Arabic, therefore, French and English were

$5^{1} \quad$ Murre-van den Berg, Scribes and Scriptures; Heleen Murre-van den Berg, "Classical Syriac, Neo-Aramaic and Arabic in the Church of the East and the Chaldean Church between 1500 and 1800," in Aramaic in its Historical and Linguistic Setting, edited by Holger Gzella, Margaretha L. Folmer, (Veröffentlichungen der Orientalischen Kommission 50; Wiesbaden: Harrassowitz, 2008), 335-352, Amir Harrak, Syriac and Garshuni Inscriptions of Iraq, vol. 1: Text; vol. 2: Plates (Recueil des inscriptions syriaques; Paris: de Boccard, 2010), Bernard Heyberger, "Livres et pratiques de la lecture chez les Chrétiens (Syrie, Liban), $\mathrm{XVI}^{\mathrm{e}}-\mathrm{XVIII}{ }^{\mathrm{e}}$ siècles," in "Livres et lecture dans le monde ottoman," edited by Frédéric Hirzel, REMMM 87/88 (2007), 209-23. 
added to Hebrew as languages of communication among the Jewish communities of the time. ${ }^{52}$

In this regard, the Jewish communities, perhaps by virtue of their already extensive transnational networks and the ongoing dominance of Hebrew in religious circles, were ahead of the Christians and later also of Muslims who made a similar move to French and English in the early twentieth century. Compared to the early Ottoman period, when Arabic and Turkish as cosmopolitan languages (in Pollock's sense of languages that created trans-local and trans-regional linguistic communities) competed with local vernaculars and sacred languages, the late-Ottoman modernization added colonial languages such as Italian, French and later English to the mix. These new colonial cosmopolitan languages provided an alternative not only to nationalist vernaculars such as Armenian and Modern Aramaic, but also to nationalist and vernacular interpretations of Arabic and Turkish. ${ }^{53}$ From the late eighteenth century onwards, Italian, French and Russian as used by the European powers gradually extended their influence over the Middle East. Whereas in the early Ottoman period Italian was still very important due to the trading connections with the Viennese and Genoese, French gradually replaced Italian for diplomatic and ecclesial purposes, although both Latin and Italian lingered on as languages of the Roman Catholic Church, as described by Leyla Dakhli in this volume. Russian grew in importance in the late eighteenth and early nineteenth centuries, when the interactions between the Orthodox Middle East and imperial Russia intensified. While the full impact of these languages did not reach the majority of the population until far into the twentieth century, when French was forced to yield to English, in the Christian and Jewish worlds the impact of European languages and literature was felt already long before that. Translations, initially from Italian and French, later also from English, played an important role in missionary work, and these mostly religious productions in turn stimulated the emergence and development of a secular literature in Arabic, Turkish and the various vernaculars.

52 Goldstein-Sabbah, this volume; Jacob Mansour, The Jewish Baghdadi dialect: Studies and Texts in the Judaeo-Arabic dialect of Baghdad (Or Yehuda: The Babylonian Jewry Heritage Center, the Institute for Research on Iraqi Jewry, 1991), Benjamin Hary, "Judeo-Arabic: A Diachronic Reexamination," International Journal for the Sociology of Language 163 (2003): 61-76.

53 Cf. Hoda A. Yousef, Composing Egypt: Reading, Writing, and the Emergence of a Modern Nation, 1870-1930 (Stanford CA: Stanford University Press, 2016), 140-1: "In this atmosphere [colonial Egypt, ca 190o], language became a natural arena of cultural, economic, and political competition: Arabic became the language of national and cultural pride, just as English and French were the languages of social and political power." 


\section{5}

\section{A Few Conclusions on the Ottoman Period}

Looking back on the various Ottoman cases discussed so far, the first conclusion must be that vernacularization played a much larger role than has been recognized so far, not only in the nineteenth century, but also in the seventeenth and eighteenth centuries. Religious specialists everywhere took vernacular languages as their starting point in developing new forms of written language. Some of these newly written vernaculars were unique to the specific groups using them, for instance Aramaic, Kurdish, Armenian or Bulgarian. Others took up or continued to write in the major literary languages of the region: Turkish, Arabic and Persian. Notably, many of the texts written by Christians and Jews in this period self-consciously used vernacular forms of these cosmopolitan languages rather than adopting the most formal and standardized levels of the language. The distinction, therefore, between writing vernacular and cosmopolitan languages, however important for initial analysis, creates the risk of overlooking the shared interest in modernization and vernacularization, in developing a form of writing that is close to the spoken language of the majority of the people, with the explicit aim of engaging a larger group of people in the modernization of religion and society.

This leads to the second observation, namely that all these forms of linguistic and literary innovation in one way or another were initiated by religious men and a few women. It was local bishops, priests, monks, nuns, mullahs, rabbis and religious teachers of all kinds, in tandem with or in opposition to missionaries and educationalists from outside, who initiated this important phase of linguistic and educational renewal. They, rather than secular rulers, were the ones that spurred this important phase of what for the Middle East (as for Europe) is as much "early" as it is "pre"-modern. The first impetus to literarization and wider education was intimately connected with the essentially religious aim of deepening religious knowledge and religious commitment. As Leezenberg reminds us: this process "also involves new linguistic ideologies that present vernaculars as eloquent, expressive and worthy for the writing of high literature. ${ }^{.54}$ Note that whereas we have stressed the local impetuses for these developments, the above also makes clear, in line with Pollock, that vernacularizations always in one way or another react to cosmopolitan models of literature and literization and so never develop in a vacuum. ${ }^{55}$

$54 \quad$ Leezenberg, this volume.

55 Pollock, The Language of the Gods, 26. 
Thirdly, this educational and paraenetic aim explains the preferential use of communal scripts for the cosmopolitan languages as much as for the local vernaculars. This habit has often been explained as a form of early identitarian practice, as setting oneself visibly apart from others who use the same language. In the same identitarian vein it has been suggested that the practice of using communal scripts might have been a way to hide what was written from outsiders who had no business with it. In light of the overall religiouseducational impetus of these early forms of vernacularization and literarization, it seems more likely that the primary reason for the use of communal scripts was a pragmatic one: the fact that this was the script that was easiest for people to use. It was the script authors from an early age had been trained to read and write, and it was the script that its potential readership would have known, if only superficially, since childhood. Every other script would have been more difficult to write and teach. This rootedness in existing educational practices is confirmed by the fact that as soon as general and standardized education took hold in the late nineteenth and early twentieth centuries, the communal scripts in use for Arabic started to disappear. From then on, for the majority of readers and writers their first letters were Arabic (for both Arabic and Turkish), and hence the practical need for a different script disappeared. It is only when in the first decades of the twentieth century other scripts became the pragmatic option that these communal scripts in some contexts (for example the Syro-Ottoman and Syro-Arabic) became part of identitarian practices, as a conscious choice over and against the pragmatic use of the everyday scripts. ${ }^{56}$

Fourthly, it is important to note that the near-disappearance of the communal scripts for Arabic and Turkish is related to, but does not exactly parallel, the gradual disappearance of the communally distinct forms of Arabic and Turkish. Already in the nineteenth century these communal forms of Arabic and Turkish started to give way to forms much closer to the literary forms of the majority, with the various forms of language being used alongside each other, depending on author and intended audience. In this way, the more informal and modern forms of Arabic and Turkish that were used by Armenian, Syriac and Rum Orthodox communities may have contributed considerably to the new forms of Ottoman Turkish and Ottoman Arabic that emerged in the

56 Tijmen Baarda, "Standardized Arabic as a Post-Nahḍa Common Ground: Mattai bar Paulus and his Use of Syriac, Arabic, and Garshuni," in Goldstein-Sabbah, Murre-van den Berg, Modernity, Minority, and the Public Sphere, 71-95; Kiraz, Túrāṣ mamllā; Moreen, In Queen Esther's Garden, 10-11, for Judeo-Persian in Hebrew script adds that this writing tradition existed prior to the introduction of Arabic script in Iran, and thus speaks of "retention" rather than adoption of Hebrew script for this language. 
nineteenth century. Over time, these intercommunal and modernized forms of Arabic and Turkish formed the basis for the standardized and nationalized languages of the twentieth century, being forged out of the contributions of writers and readers from most if not all communities of the Ottoman Empire.

Fifth and finally, the above overview also indicates that the linguistic situation in the Middle East was not only complex but also extremely fluid. If anything becomes clear from the above, it is that belonging to one community does not a priori lead to the use of one specific language (or language variety) and literary tradition. At the same time communal choices and communal boundaries remain important for understanding the developments of the sixteenth to nineteenth centuries. While recent scholarly discussions about the nineteenth-century transformations of the Ottoman communal system in the context of the Tanzimat reforms have focused on the hardening and politicization of communal boundaries, ${ }^{57}$ the literary developments indicate that at the same time, and not necessarily in opposition to it, the first outlines of a common, overarching literary world were created. Some of the very local and communal vernacular impulses of the seventeenth and eighteenth centuries transformed into separatist nationalisms, as with the Greeks, the Bulgarians and the Armenians. At the same time, however, parts of the Rum-Greek and Armenian communities participated in the emerging Ottoman literary world, writing in Turkish and Arabic in ways that were not strictly communal. A variety of influences, from within the communities, from co-religionists elsewhere and from inside and outside the region, subtly pushed language use in this or that direction, especially because little to no governmental or communal force was applied to stimulate the use of one language or another, or one form of a particular language or another.

\section{Nationalizing Language}

Although the role of the state in language matters was fairly limited up to the early twentieth century, this changed after the First World War. Language became a political tool in the hands of the British and French Mandate governments entrusted with the task of setting up new states, and just as much in the hands of local and regional nationalists within and outside the governmental structures. As one may expect, these tendencies were in no way clear-cut or

57 Ussama Makdisi, The Culture of Sectarianism. Community, History, and Violence in Nineteenth-century Ottoman Lebanon (Berkeley, CA: University of California Press, 200o). Makdisi himself describes the opposite movement in Artillery of Heaven (quoted above). 
unidirectional, even if all of them were guided by ideals of homogenization, standardization and vernacularization. The Foucauldian term "governmentalization," as used by Leezenberg to characterize the developments of Kurdish in North Iraq, attempts to capture this characteristic amalgam as it developed in the first half of the twentieth century, stressing the mutual dependence and interaction between governmental and non-governmental actors. ${ }^{58}$

Before we zoom in on the nascent Arab states it is worthwhile to start with a brief look at the developments in Anatolia, where the new Turkish state transformed Ottoman Turkish into the Turkish of the new state. In a radical departure from earlier phases of the language, a new Latin alphabet-based script was forced upon readers and writers in 1928. In addition, the vocabulary was purged of 'foreign' words as much as possible, chiefly among them words from Arabic and Persian. This radical modernization, standardization and simplification of the language certainly made it accessible to a much wider readership than in the pre-war period, but it also barred modern readers from earlier Turkish literature in its wide variety. What is more, symbolically if not effectively, it separated the new Turkey from the wider Middle East, its former Arab provinces and its neighbour Persia, implying that the new Turkey looked north and west more than south and east. ${ }^{59}$

This radical linguistic reform paralleled the wished-for Turkification of society as a whole, which even after massacre, expulsion and population exchange was not homogeneously Turkish in the ethnic sense. In addition to small remnants of the communities that had been targeted during the First World War and after, i.e., Greeks, Armenians, Syriacs and Chaldeans, Jews and especially Kurds were now also more conspicuous than ever as outsiders vis-à-vis the Turkish state. While the possibilities for using their communal languages and scripts were severely limited by the state, Turkish became the norm for reading and writing all over the country by virtue of an obligatory school system. As described by Emmanuel Szurek in this volume, one of the elements of Turkification was the proposal for a general introduction of Turkish or Turkified surnames. ${ }^{60}$ His contribution makes clear that this plan contained some contradictory elements and was not only targeted at non-Muslim minorities. In the first phase, in the summer months of 1934, the aim was to have everyone change their names to fit to Turkish patterns, that is, to discard names reflecting what were perceived as foreign identities. This included names such

\footnotetext{
58 Leezenberg, this volume.

59 Geoffrey Lewis, The Turkish Language Reform: A Catastrophic Success (Oxford: Oxford University Press, 1999).

6o Emmanuel Szurek, this volume.
} 
as Mehmet-the-Kurd, but also name endings reflecting the Ottoman past, such as -pasha and -bey, and those specific to particular subgroups, such as the Armenian -ian/-yan or Persian -zade. The Surname Reform proposal was coupled with a reform of place names, in which non-Turkish names were replaced by Turkish ones. Rather surprisingly, and hardly noticed by scholars so far, by the end of 1934 the phrase demanding removal or change of all foreign names and suffixes was replaced by a much less far-going phrase, mentioning only "names of foreign races and nations" (thus, from the examples above, only "Mehmet-the-Kurd"). Szurek interprets this rather sudden change as simultaneously allowing non-Muslim minorities to keep their own names and keeping them separate and distinct, barring them from assimilation, and focusing on differentiation. More research is needed here, but it seems that over time the drive towards linguistic homogenization again became dominant, excluding most non-Turkish names from public and legal use.

Such large-scale governmental homogenizations were never attempted in the regions that were governed by the British and French, although there, too, linguistic ideologies and practices played a fundamental role in the creation of the new nation states. The main focus of this volume is on the areas that were under British-Mandate government, and therefore the French areas provide some interesting material for comparison. This is particularly true for Lebanon, which provides a fascinating, if unique, case of a linguistic conundrum. As in many other regions where French rule was instated, ${ }^{61}$ French became the language of choice in government and education, even if Arabic was taught in most schools at the initial levels. Higher education, however, was conducted solely in French, so that "being educated" became almost synonymous with "being Francophone." This focus on French was accompanied by a somewhat convoluted relationship with the newly standardized fușha. This form of Arabic, as was indicated in the previous section, had strong connections to Beirut and Lebanon as a whole, with Christians such as Butrus al-Bustani being among those espousing it. As mentioned in Salameh's article in this volume and in his more extensive monograph on the same topic, in the 1920 and 193os fuṣ. a or Standard Arabic became politically associated with a pan-Arab nationalism that connected Lebanon with the wider Arab world, in particular

61 Hans-Georg Wolf, "British and French language and educational policies in the Mandate and Trusteeship Territories," Language Sciences 30,5 (2008): 553-574. Although he writes about the C-Mandates, Wolf's analysis of the differences between the French (top-down francophonie) and the British areas (more space for local actors and local languages) basically seems to hold true for the Middle Eastern Mandates as well. 
with Syria as a whole. ${ }^{62}$ Peter Wien's contribution on Fu'ad al-Khatib, who was originally from Lebanon (the Shouf) introduces the case of one such Sunni Muslim contributor to a linguistically based pan-Arabism. According to Wien, al-Khatib was an uprooted man seeking the foundations of communal identity in the pure language of the Hejaz, creating the "chronotope of an idealized, historically and geographically defined location intersecting with that of the author."63

To many, the French language symbolized the opposite: not an Arab identity looking southeast to the Hejaz, but a distinct Lebanese identity that stood at the crossroads of (Middle) Eastern and Western influences. This was usually framed as the typical "Phoenician heritage" of the country that separated it from the rest of the Arab Middle East. In turn, this Phoenicianism gave birth to new linguistic theories supporting a uniquely Lebanese language: either a "Syriac" or "Aramaic" language that supposedly was only recently lost as a vernacular and whose memory was kept alive in the (Classical) Syriac elements of the liturgies of the Maronite and Greek churches, or the Arabic Lebanese vernacular, but then interpreted as a creole language which had fused elements of Phoenician, Syriac and Arabic. While the latter is linguistically unconvincing and the former rather impractical, the combination of new historical interpretations with linguistic data provided further basis for a separatist, Lebanese, non-Arab identity that has inspired politicians, activists and intellectuals until today. Religion was an important factor in these identitarian practices. Christians, especially of the Maronite Church, were more inclined to variations of the Phoenician theory. Muslims, both Sunni and Shiite, tended towards the Arabic-based versions of Lebanese or pan-Arab nationalisms. However, these connections were not exclusive, because they ran along denominational (Rum versus Maronite) as much as religious (Muslim versus Christian) lines, and because linguistic choices were strongly influenced by socio-economic and regional parameters that did not run parallel to religious ones. ${ }^{64}$

One other noticeable aspect of linguistic practice in Lebanon is that despite an overall tendency towards French and SA as the major languages of

62 Franck Salameh, Language, Memory, and Identity in the Middle East: The Case for Lebanon (Lanham, MD: Lexington Books, 2010), Salameh, this volume.

63 Peter Wien, this volume. Notably, George Antonius, a Lebanese/Palestinian Christian, also saw the Hejaz as the original region of the idealized Arab and Arabic, see Murre-van den Berg, "The Language of the Nation.".

64 On Phoenicianism, see Salameh, this volume; Asher Kaufman, Reviving Phoenicia: The Search for Identity in Lebanon (London, I.B. Tauris, 2004/2014). Suleiman, The Arabic Language, 204-219, and Joseph, Language and Identity, esp. "Case Study 2: Christian and Muslim Identities in Lebanon," 194-223. 
the country, there was ample space for other languages. In fact, as Nicola Migliorino concludes in his study on the Armenian communities of Lebanon and Syria:

The comparatively successful preservation of Armenian ethno-cultural diversity in Lebanon and Syria may be described - rather paradoxically as a "by-product" of the two states' unresolved search for a solution to the political problems raised by the non-homogeneity of their society [...] because the stability of the state could not do without it until a more solid legitimacy, based on cross-cultural allegiances and cleavages could be found. ${ }^{65}$

The majority of Armenians in Lebanon, clustering together in the northern suburbs of Beirut, were survivors or children of survivors from the Anatolian genocide. Many of them had Western Armenian as their primary language, so that those who used to speak Turkish had to learn a new language. While some in the community quickly adopted Arabic and French and integrated in the wider Lebanese community, others remained in the safety of the Armenian community, learning Armenian and sometimes French in communal schools, praying, working and living family lives completely in Armenian. The community of Beirut was in close contact with that of Aleppo, the largest one in the Arab Middle East, where a similar situation of multilingual practice was maintained even after the creation of the Syrian state. Printing presses in Aleppo and Beirut catered for the wider Armenian community, in Syria and Lebanon, but also in Iraq, Turkey, Palestine and in the West, especially in the United States. Locally, theatres staging Armenian plays were important in sharing Armenian language, traditions and socio-political concerns. Thus, the Mandate period allowed the Armenians to take a new step in creating a transnational community that tended to refrain from getting involved in local nationalist politics, in Lebanon, Syria or elsewhere, and rather focused on maintaining, strengthening and expanding a strong transnational Armenian communal identity based on the two pillars of language and religion. ${ }^{66}$

65 Nicola Migliorino, (Re)Constructing Armenia in Lebanon and Syria: Ethno-Cultural Diversity and the Sate in the Aftermath of a Refugee Crisis (New York: Berghan Books, 2008), esp. 223 .

66 For political and literary trends in this period, see Migliorino, (Re)Constructing Armenia; for the political context in Syria, especially Aleppo, see Keith David Watenpaugh, Being Modern in the Middle East. Revolution, Nationalism, Colonialism and the Arab Middle Class (Princeton: Princeton University Press, 2006). 
For the Syriac Christians the situation was similar, though overall the Syriac communities were smaller and divided over more churches. The Syriac Orthodox Christians that survived the genocide of 1915 settled in much the same places as the Armenians, although a small group remained in southeast Anatolia, in the Tur 'Abdin area. Others ended up in Lebanon, Syria (mostly Aleppo and the northeast) and Palestine, while the northern-Iraqi community more or less kept in place. They too tended to focus on the survival of their communal language and religion rather than invest in the nationalist discourses of the host-states in which they ended up after the war. As among Armenians, printing presses became active in Beirut, Aleppo and Jerusalem, new dioceses were created, and schools were maintained. Arabic played a larger role among the Syriac Orthodox than among the Armenians, probably because the pre-war percentage of Arabic speakers among them was larger, and there was no working equivalent to modern Western Armenian among the Syriac Orthodox. Nevertheless, Syriac Orthodox clerics in Syria and Iraq endeavoured to promote Classical Syriac as the most important language of the community. This included attempts to write the language in a modernized form for non-clerical purposes. ${ }^{67}$

Arabic in its modern form was dominant in Iraq. From 1931 onwards, Standard Arabic became the language of education in all schools with government funding. Communal schools that additionally taught other languages, however, were allowed and often thriving. ${ }^{68}$ Baarda describes how in the Syriac community the use of and commitment to Syriac varied considerably. In the Assyrian schools Syriac in its modern and classical forms was taught alongside French and English, although there, too, Arabic was the dominant language from 1931 onwards. The clergy on the whole supported Syriac rather than Arabic, though most mastered both languages. At the other end of the spectrum, the Chaldean hierarchy, in cooperation with the Dominican missionaries in Mosul, espoused the use of Arabic within their communities, also in ecclesiastical contexts. They saw themselves as loyal citizens of the new state and the promotion of

67 Khalid S. Dinno, The Syriac Orthodox Christians in the Late Ottoman Period and Beyond: Crisis then Revival (Piscataway NJ: Gorgias Press, 2017) (especially Ch. 6 on the literary innovators of the early twentieth century, Patriarch Aphram I Barsoum, Bishop Philoxenus Yuhanna Dolabani, Ni'matullah Denno and Na'um Faiq), Heleen Murre-van den Berg, "Classical Syriac and the Syriac Churches," and Murre-van den Berg, "A Center of Transnational Syriac Orthodoxy: St. Mark's Convent in Jerusalem," Journal of Levantine Studies 3,1 (2013): 61-83. See further Isaf and Baarda in this volume.

68 Baarda, "Standardized Arabic," and Sasha Goldstein-Sabbah, "Jewish Education in Baghdad: Communal Space vs. Public Space," both in Goldstein-Sabbah, Murre-van den Berg, Modernity, Minority, and the Public Sphere, 71-95 and 96-120. 
Arabic was part of that. Among the Syriac Orthodox of Iraq similar trends can be noted, though less pervasive than among the Chaldeans. Baarda argues that the use of and commitment to standardized Arabic was mostly a phenomenon found among the Chaldeans and Syriac Orthodox in the urban areas. In the rural hinterland, Sureth (Modern Aramaic/Syriac) remained the majority language within all three communities. In the Assyrian Church of the East, Sureth was dominant even in the cities, and only a small group of Assyrians in some way or another were involved in the emerging Arabic Republic of Letters. ${ }^{69}$

Despite the relative freedom in the early Mandate years to teach other languages in addition to Arabic, Leezenberg argues that the further literarization of Iraqi Kurdish varieties, most importantly the Sorani dialect, owed most to private initiatives outside the educational system. ${ }^{70}$ Plays and poetry, both written and performed, were much more important in furthering the use of Sorani than attempts to standardize and homogenize the language via the writing of grammars. The Local Languages Law of 1931, as instated by the British, contained provisions for the teaching and use of Arabic, Turkish and Kurdish (but none of the other languages such as Syriac or Armenian), but already in the 1940s "Kurdish was removed from the primary school curriculum altogether."71 The Baathist years made teaching of and in Kurdish increasingly difficult and though this changed radically after the semi-independence of 1991, both political and practical issues prevented the development of a fullyfledged standardized and homogenized literary language that encompassed at least the Iraqi varieties of Kurdish.

As described earlier by Sasha Sabbah-Goldstein the situation was very different in the Jewish schools, with gender and class accounting for some of the differences. In addition, the schools sponsored by the Alliance Israélite Universelle were strongly French oriented, to the detriment of Arabic, which in the schools of the British Anglo-Jewish Association received more attention. ${ }^{72}$ In her contribution to this volume, considering the important status of Arabic in some of the schools and noting its overall increase during the 1930s, Goldstein

69 Tijmen Baarda, this volume. For the Assyrians, this was to change with the onset of the large-scale migration to the cities, especially to Baghdad, in the 196os - from that time onwards, their men and a few women of letters participated in the Arabic Republic of Letters. One of the most famous in the literary sphere was the poet Sargon Boulos (1944-2007).

$70 \quad$ Leezenberg, this volume.

71 Leezenberg, this volume.

72 Goldstein-Sabbah, "Jewish Education in Baghdad;" on Jewish participation in SA in Iraq, see Orit Bashkin, The Other Iraq: Pluralism and Culture in Hashemite Iraq (Stanford: Stanford University Press, 2009). 
describes the linguistic situation as one of "linguistic pragmatism" encouraged by the strong focus of the mercantile upper classes on English and the British Empire. In a development starting in the 186os, by the 1930s economically and socially leading families had firmly settled in Hong Kong, Shanghai, India and England. From there, they kept in close contact with their family members back in Baghdad and actively supported communal and educational ventures there. Thus, by supporting the local Jewish community of Baghdad, these expatriate Baghdadis simultaneously undermined such a purely local commitment and outlook. Through the mercantile settlements abroad, where English was the main language of communication, the Sassoons and the Kadouries (to mention only two of the most important families), allowed the Baghdadi Jews not to put all their hopes on the Arab Iraqi state by providing opportunities for transnational travel and identification with a larger Jewish community.

This also included solidarity with the emerging Jewish colony in Palestine, where the linguistic situation was the most complicated of all. More than half of the contributions in this volume focus on Palestine. At the official level, British policy was fairly straightforward, with three languages, Arabic, Hebrew and English used alongside each other for all official communication, as evidenced amongst others by the stamps that were used in this period. ${ }^{73}$ As such, the British Mandate stimulated not only the use of English (in addition to and instead of French, German and Italian), but also the further modernization and nationalization of Arabic and Hebrew. At the beginning of the Mandate, both languages in their modernized forms were far from uncontested within Muslim, Christian and Jewish circles. Among the Jews in Palestine, Modern Hebrew was just one among many other languages, which included German, Yiddish, French, English and Arabic. Among Muslims and Christians, it was not only French and English, but also different varieties of Arabic that played a role. The mere fact, therefore, of the British Mandate's official endorsement of SA as the language of the "Arabic" community, and "Hebrew" for the Jewish community, endorsed and supported specific nationalist tendencies in each of these groups, the rhetoric of those who saw Hebrew as the one and only language of the Zionist settlement, with Standard Arabic in a similar position for the emerging Palestinian nation. How the various languages competed with each other within the Jewish community is the subject of Liora Halperin's monograph Babel in Zion. In the current volume she follows this up with a discussion of the role of Arabic in the Jewish community. Halperin analyzes the role of Arabic in the earliest Zionist settlements in which spoken Arabic

73 Yair Wallach, "Creating a Country through Currency and Stamps: State Symbols and Nation-building in British-ruled Palestine," Nations and Nationalism 17,1 (2011): 129-147. 
had been an integral part of the linguistic repertoire, used especially to communicate with Arab labourers. In hindsight, when some in Jewish settlements had started to prefer separation and "Hebrew labour" over and above more entangled forms of coexistence between Jews and Arabs, these early forms of cooperation, which often had been mediated by Jews with Middle Eastern backgrounds, were nostalgically presented as early examples of Ashkenazi Jewish engagement with the local Arab world. ${ }^{74}$

Two further contributions address the well-known tensions between Greek- and Arabic-speakers among the Rum Orthodox Christians of Palestine. Konstantinos Papastathis situates the importance of Arabic among the Rum community within its larger historical context, focusing on the tensions between Greek-speaking and Greece-trained clerics and Arabic-speaking lay people of Palestine. ${ }^{75}$ Merav Mack adds an important dimension to this by looking at the Greek-speaking lay communities, mostly descendants of Greek merchants that settled in the Levant in the late nineteenth century. She shows that while the majority of lay Rum Christians were Arabic speaking, this was not true for everyone. ${ }^{76}$ Both authors, however, point out that as a result of intermarriage, socio-economic ties, and geographical overlap, there was in practice no absolute division between the two communities. Over the Mandate years Arabic grew in importance for everyone, even if Greek, and sometimes also a continuing bond with the Greek state, never disappeared completely from lay circles.

Finally, Layla Dakhli discusses the linguistic situation among the "Latin" and other Catholic Christians of Palestine. As Karène Sanchez argued elsewhere, for these Catholics it was French rather than Arabic or English that initially dominated the scene. Sanchez describes how Arabic replaced French as part of the rising nationalist tide, contributing to the build-up of a common front against the growing socio-political and economic dominance of the Jewish communities. English also made its way into the Latin Catholic communities, mostly as a means to acquire jobs within the Mandate government. French continued to be taught, however, though much less intensively so, but in many

74 Liora Halperin, Babel in Zion:Jews, Nationalism, and Language Diversity in Palestine, 19201948 (Yale: YUP, 2015); Liora Halperin, this volume. On Arabic in the Jewish communities of Palestine, see Ori Shachmon, "Halabi Arabic as a Contact Dialect in Jerusalem," Journal of Jewish Languages 5 (2017): 49-80.

75 Papastathis, this volume; Papastathis, "Religious Politics in Mandate Palestine: The Christian Orthodox Community Controversy in the Thirties," British Journal of Middle Eastern Studies 43,3 (2016): 259-284; for background, see Panchenko, Arab Orthodox Christians.

76 Mack, this volume. 
ways it remained an important second language in addition to vernacular and standardized Arabic. ${ }^{77}$ Sanchez in particular stresses the important role of the Roman Catholic missionary schools in this process. More or less tied to Vatican-based linguistic policies, the schools slowly adapted to the increased demand for teaching of and in Arabic. These languages all found their way to the printing press of the Franciscans, in the Old City of Jerusalem. In this volume, Leyla Dakhli describes how the Franciscan press in the Mandate period (somewhat surprisingly considering its ongoing ties to the clerical Catholic establishment) functioned mostly as an independent commercial press that used its expertise in multilingual printing to work for the British government as much as for private organizations (including churches and missionary congregations) and individuals. Perhaps less surprising, its Italian connections also made it a preferred venue for printing work ordered by the Italian government for their North-African colonial adventures, thus serving the fascist government which for most of the period was among the political opponents of the British Mandate government. If anything, those deciding on the production of the Franciscan press took to its extreme the actual linguistic pragmatism that many of the authors represented in this volume have noted.

If only one thing was to be underlined at the end of this introduction, it would be the fact that, as in the case of the Syriac Christians with whom we started, for many people living in the Middle East there are no exclusive connections between religion, ethnicity, nationality, and language, even if at the same time languages continue to be used as important markers in ethno-religious identity debates. The inherent instability that results from these ever-changing connections makes it impossible to provide a representative snapshot, whether concerning pragmatic linguistic choices or political loyalties. It is the movement in one direction or another that is more telling than the actual situation at any given moment, and it is patterns and parameters that have explanatory power rather than straightforward causal relations. It is precisely for that reason that we took the time (in this introduction but also in several of the contributions) to start our discussion of the Mandate period with the Ottoman period that

77 Karène Sanchez, "Linguistic diversity and ideologies among the Catholic minority in Mandate Palestine. Fear of confusion or powerful tool?," British Journal of Middle Eastern Studies 43,2 (2016): 191-205 and Sanchez, "Preserving Catholics of the Holy Land or integrating them into the Palestine nation? Catholic communities, language, identity and public space in Jerusalem (1920-1950)," in Goldstein-Sabbah, Modernity, Minority, and the Public Sphere, 121-151. 
preceded it, laying bare some of the longer ongoing trends and developments that not only set the scene for what happened from the 1920 s onwards, but also uncover the parameters along which the interplay between religion, language and nationalism developed.

The Ottoman period saw many instances of what Sheldon Pollock has called vernacularization, in the sense of adapting spoken or existing written languages to a form that was understandable to and learnable for more people than merely the small educated classes of priests, religious experts or government officials. Often this started with paraenetic writings serving as a memory aid for religious experts, but soon these new written forms were also used in education and thus contributed to the spread of reading and writing. In many places these attempts at vernacularization were accompanied by the establishment of printing presses, either in the region (Istanbul, Mount Lebanon) or outside it (Venice, Vienna, Amsterdam). The cases of the Jewish, Syriac Christian, and Muslim Kurdish communities of North-Iraq show that vernacularization could also start without printing presses, by expanding and modernizing existing manuscript cultures.

Another major conclusion of the above is that vernacularization in this general sense encompasses a number of different linguistic choices, grounded in different starting points. Some started from a long history of participation in the cosmopolitan languages of the region in their written and spoken forms, with more authors gradually joining while expanding the range of genres. Thus these non-Muslim authors became crucial contributors to the later modernized and standardized forms of Arabic and Turkish, even if for most of the Ottoman period they wrote in their communal scripts. Others prioritized their communal languages in written and spoken forms, and either chose to vernacularize the classical liturgical language or started to standardize and literize the spoken vernaculars. The first option usually was too closely linked to religious specialists to survive the secularizing trends of the nineteenth century; the second became wedded to the nationalist movements of the nineteenth and twentieth century. Depending on political circumstances, these efforts were more or less successful in creating fully-fledged communal and literary languages. Despite their differences, these three forms of vernacularization share a rootedness in the religious modernization of the sixteenth and seventeenth centuries, their initial religious paraenetic aims (hence also the use of communal scripts), and their mostly nineteenth-century adoption of additional secular and nationalist goals, aiming at modernizing and transforming the community as a whole. Their protagonists were certainly influenced by European (including Russian) examples, but we may conclude that especially in the early phases of vernacularization local needs and local impulses were dominant. 
The study of these three types of vernacularization alongside each other allows us to discern the underlying tensions in the nineteenth-century nationalist projects. Indeed, in a number of communities, among which Middle Eastern Jews, Armenians and Syriacs, all three trajectories of vernacularization were explored and developed simultaneously. While this was hardly a problem in the paraenetic phase, when language choice was very much guided by local concerns and local aims, this became more complicated in the nationalist phase. At that point, language came to be seen as a tool for unifying and strengthening the newly conceptualized 'nation,' as it did in Arabic, Turkish and Persian circles, along the lines of Sati' al-Husrî's often quoted phrase that Arabic was to be seen as "a unified and unifying language." This forced literary elites to argue against such instable and multiple linguistic norms, because these could easily be interpreted as undermining nationalist unity. Thus, from the early twentieth century onwards what used to be pragmatic choices of one language over another became increasingly imbued with political meaning.

However, the nationalization and governmentalization of languages during the Mandate period had fewer straightforward effects on the use of additional languages than one may have expected. This is particularly true for Arabic, the central subject of this volume. Undoubtedly, the use of Arabic, with its newly gained governmental status, increased among all segments of the population. The simple but effective control of language education in schools and the use of modernized Standard Arabic in government ensured that every citizen was forced to learn the language. This was true also among those rural populations that prior to the Mandate period had had little or no interest in learning to read and write in Arabic - the Jews of Iraq, in Kurdistan as well as in Baghdad, the Syriac Orthodox Christians of the Nineveh plains and the Kurdish mountains, the Assyrians of North-Iraq and northeast Syria. Similarly, the Anatolian and Hakkari Armenians, Syriac Orthodox, Assyrians and Catholics of the various denominations that after 1915 ended up in Syria, Lebanon and Palestine, were forced to learn Arabic in order to thrive in their new homelands. While for the majority of these new users of Standard Arabic this comes across as a very pragmatic choice, some among them, for intellectual, political and socioeconomic reasons, put their full force behind it and actively participated in and engaged with the newly created Arabic Republic of Letters, making it into an interreligious, even secular, space for exchange and nation building.

At the same time, however, when Arabic became the preferred language for political and societal modernization, other languages were practiced: the spoken vernaculars (which also included non-standardized forms of Arabic), a variety of communal religious languages, and the cosmopolitan colonial languages that came with the Mandate governments, French and English. While 
in all non-Muslim communities there were those who publicly advocated the exclusive use of one or another language (either to join state nationalisms, or to promote separatist nationalisms of the Zionist, Armenian or Assyrian types), in practice the majority of readers and writers went on juggling a variety of languages alongside one or more spoken vernaculars, often participating in more than one Republic of Letters: Arabic on the one hand, and Syriac, Armenian, English, French, Hebrew, Yiddish or German on the other. Distinct Republics of Letters, which, however, due to the geographical and human proximities, continued to mutually influence each other.

All of this suggests that religious belonging in the legal sense in most Middle-Eastern states is not an independent factor that predicts the use of one language or another, or support for one language ideology or another. Belonging to one religion or denomination or another predicts a certain level of knowledge of the characteristic language of the community ('Armenian' in case of Armenians, 'Hebrew' in case of Jews), but this "certain level of knowledge" could vary from next to nothing to in-depth literacy combined with active writing skills. What this level is, and what other languages someone would be able to use, depends on additional factors such as region, socio-economic status, profession and gender. The main counterexample to this generally weak link between language and religion is the fairly strong connection between Catholicization and Arabization that various researchers have noted for the Ottoman period. However, while communities that converted to Catholicism at an early stage were often more Arabized and continued to Arabize after becoming part of the Catholic Church, and while Arabic became a language of inter-Catholic communication in the Ottoman period as well as later in the twentieth century, it is also clear that communal languages such as Syriac and Armenian survived and in fact flourished in Catholic circles. Thus, although Catholicism might be a contributing factor to Arabization (and vice versa, Arabization to Catholicization), it does not appear to be the overriding one. The same seems to hold true for Protestantism, within which Arabic is dominant but again with a sufficient number of counterexamples to make a one-to-one causal relationship untenable. What comes across much more strongly, however, when we survey material from the Mandate period, is that the closest correlations between the primacy of Arabic and the primacy (ideological and in practice) of another language are to be found along the boundaries between urban and rural, between those involved in the Arab nationalist projects and those either politically quietist or involved in one of the counter projects, Assyrian, Armenian or Zionist. These boundaries proved to be more important to explain language difference than those between religions or denominations. 
In February 2017, Yacoub Shaheen from Bethlehem won the fourth edition of Arab Idols with impressive performances of classical and modern Arabic songs including nationalist Palestinian ones. He was hailed all over the Arab world and the Arabic-speaking diaspora as a representative of the Palestinian people. At the same time, Syriac Orthodox Christians hailed him as one of their own, doing some vigorous Facebook-campaigning to have the diaspora vote for him. Clips and images were shared of Shaheen singing as a deacon in the Syriac liturgy, marching as a Syriac scout in Bethlehem, and, most importantly, of Shaheen wearing the red-and-yellow Syriac/Aramean flag in addition to the Palestinian flag or black-and-white kufiyah that he also was photographed with. In interviews, Shaheen stressed that he spoke Aramaic as well as Arabic, refraining from choosing between the two, but in the Christian diaspora verbal fights focused on whether he was "Assyrian" or "Aramean." In these circles, his identification with the Palestinian cause was passed over, to the point that stories were told that he had been pressured into hiding his Aramaic identity on television. ${ }^{78}$

Language is one of the strongest cultural tools that groups have at their disposal, making what at first sight seems a straightforward matter of choosing the best means of communication into a specialized instrument for creating and maintaining group identities. However, it does so in two ostensibly opposing ways, both of which have been exemplified in the preceding essay. The first of these is the most obvious and explicit, aiming at the formation and strengthening of group identities by the propagation of one particular language or language form as the defining characteristic of the group. Those belonging to the group appropriate this language as their own and theirs only, irrespective of whether they read and write it, speak a variety of it, or merely acknowledge its importance for the group. Whether this group becomes a 'nation' with a 'state,' or remains a so-called ethno-religious group without a specific territory they can call their own, a specific form of language has become one of its prime banners. The second approach, situated at the level of both individual members and national or ethnic leadership, fully maintains multilingualism as the

78 See, e.g., the articles on Al-Jazeera (http://www.aljazeera.com/news/2017/o2/palestinian -christian-yacoub-shaheen-wins-arab-idol-170226180221063.html; last seen 27/2/17), The National Arts (http://www.thenational.ae/arts-life/television/palestinian-yacoub -shaheen-wins-fourth-season-of-arab-idol, last seen 27/2/17), Aramese Federatie (Dutch) (https://aramesefederatie.org/2017/02/27/arameeer-wint-arab-idol/, last seen 27/2/17), Haaretz (http://www.haaretz.com/middle-east-news/palestinians/1.773855, last seen 27/2/17) and Alex Shams, 'Yacoub Shaheen, the Assyrian singer from Palestine taking Arab Idol by storm,' (https://ajammc.com/2017/02/17/yacoub-shaheen-assyrian-palestine/, last seen $20 / 3 / 2019$ ). I have not come across interviews in Hebrew or English, two other languages Shaheen could be expected to be conversant in. 
norm in the Middle East. This pervasive and mostly flexible multilingualism allows groups and their members to commit to different languages, to thus to different linguistic communities, without making final choices. By singing Arabic in the context of Arab idols and singing in Syriac in the context of the Syriac Orthodox church, Shaheen moves in different circles, which to some are mutually exclusive, but for others are sitting fairly comfortably next to each other.

If anything, the pervasive multilingualism of the Middle East as a whole and of non-Muslim communities in particular indicates their ongoing commitment to multiple identities, to multiple pasts, and multiple futures. Some of this is part of minority strategies worldwide, acknowledging and accepting that in order to survive one always has to steer a middle course between complete cultural and linguistic assimilation and unproductive isolation. Some of it, however, is part of the wider acknowledgement that multiple languages allow for multiple fruitful ways of engaging with the world, and for being part of multiple networks and groups, religious and otherwise. In this world of competing ideologies, be it in the Middle East or elsewhere, time and again language is politicized as the signpost of one exclusive identity or another, regional, religious, gendered, national, ethnic, socio-economic. On the one hand such politicizing contributes to the survival and development of specific languages (mainly by means of standardized education), but on the other it also tends to obscure the energizing power that this very struggle over multiple identities produces, the creativity that leads to new languages, to new texts, to new poetry, time and again.

\section{Bibliography}

Abu-Manneh, Butrus. "The Christians between Ottomanism and Syrian Nationalism:

The Ideas of Butrus Al-Bustani." Int.J. Middle East Stud. II (1980): 287-304.

Anagnostopoulou, Sia. "Greek Diplomatic Authorities in Anatolia." In Balta \& Kappler,

Cries and Whispers 63-78.

Anestides, Stavros Th. "The Centre for Asia Minor Studies and Books Printed in Karamanli. A Contribution to the Compilation and the Bibliography of a Significant Literature." In Balta \& Kappler, Cries and Whispers, 147-153.

Antonius, George. The Arab Awakening: The Story of the Arab National Movement. London: Hamish Hamilton, 1938.

Astafieva, Elena. "Imaginäre und wirkliche Präsenz Rußlands im Nahen Osten in der zweiten Hälfte des 19. Jahrhunderts (avec résumé français)." In Europäer in der Levante - Zwischen Politik, Wissenschaft und Religion (19.-20. Jahrhundert) / Des Européens au Levant - Entre politique, science et religion (XIX ${ }^{e}-X X^{e}$ siècles), edited by Dominique Trimbur (München: R. Oldenbourg Verlag, 2004), 161-186. 
Atto, Naures. Hostages in the Homeland, Orphans in the Diaspora: Identity Discourses Among the Assyrian/Syriac Diaspora. Leiden: Leiden University Press, 2011.

Baarda, Tijmen. "Standardized Arabic as a Post-Nahḍa Common Ground: Mattai bar Paulus and his Use of Syriac, Arabic, and Garshuni." In Goldstein-Sabbah \& Murre-van den Berg, Modernity, Minority, 71-95.

Ballian, Anna. "Karamanli Patronage in the Eighteenth and Nineteenth Centuries: the Case of the Village of Germir/Kermira." In Balta \& Kappler, Cries and Whispers, $45^{-62 .}$

Balta, Evangelia, Matthias Kappler, eds. Cries and Whispers in Karamanlidika Books: Proceedings of the First International Conference on Karamanlidika Studies (Nicosia, 11th-13th September 2008). Wiesbaden: Harrassowitz Verlag, Wiesbaden, 2010.

Balta, Evangelia, Mehmet Ölmez, eds. Between Religion and Language:Turkish-Speaking Christians, Jews, and Greek-Speaking Muslims and Catholics in the Ottoman Empire. Istanbul: Eren, 2011.

Balta, Evangelia, Mehmet Ölmez, eds. Cultural Encounters in the Turkish-Speaking Communities of the Late Ottoman Empire. The IsIs Press Istanbul, 2014.

Bashkin, Orit. The Other Iraq: Pluralism and Culture in Hashemite Iraq. Stanford: Stanford University Press, 2009.

Bassiouney, Reem. Arabic Sociolinguistics: Topics in Diglossia, Gender, Identity, and Politics (Washington DC: Georgetown University Press, 2009).

Bassiouney, Reem. Language and Identity in Modern Egypt (Edinburgh, UK: Edinburgh University Press, 2014).

Bauman, Richard, Charles L. Briggs. Voices of Modernity: Language Ideologies and the Politics of Inequality (Cambridge: Cambridge University Press, 2003).

Becker, Adam. Revival and Awakening: Christian Mission, Orientalism, and the American Evangelical Roots of Assyrian Nationalism (1834-1906). Chicago: Chicago University Press, 2015.

Blanc, Haim. Communal Dialects in Baghdad. Cambridge: Harvard University Press, 1964.

Borbone, Pier Giorgio. "Syroturcica 1: The Önggüds and the Syriac Language." In Malphono w-Rabo d-Malphone. Studies in Honor of Sebastian P. Brock (Piscataway, NY 2008), edited by George A. Kiraz.

Borbone, Pier Giorgio. "Syroturcica 2: The Priest Särgis in the White Pagoda." Monumenta Serica 56,1 (2008): 487-503.

Brock, Sebastian P., Aaron M. Butts, George A. Kiraz, Lucas Van Rompay, eds. Gorgias Encyclopedic Dictionary of the Syriac Heritage Piscataway, NJ: Gorgias Press, 2011.

Brubaker, Rogers, Frederick Cooper. "Beyond 'Identity', Theory and Society 29 (2000): $1-47$.

Brubaker, Rogers. Grounds for Difference. Cambridge MA: Harvard University Press, 2015 . 
Coakley, J.F. "Printing in the Mission Field," Harvard Library Bulletin 9.1 (1998): 5-34.

Coakley, J.F. "Printing in Syriac, 1539-1985 / Drucken in Syrisch, 1539-1985." In Hanebutt-Benz et al., Sprachen des Nahen Ostens, 93-116.

Coakley, J.F. The Typography of Syriac: A Historical Catalogue of Printing Types, 15371958. New Castle, DE: Oak Knoll Press, 2006.

Cohen, J.P. Becoming Ottomans: Sephardi Jews and Imperial Citizenship in the Modern Era. Oxford: Oxford University Press, 2014.

Dawisha, Adeed. Arab Nationalism in the Twentieth Century: From Triumph to Despair. Princeton: Princeton University Press, 2003.

Dickinson, Jennifer. "Languages for the Market, the Nation, or the Margins: Overlapping Ideologies of Language and Identity in Zakarpattia." Int.L. J. Soc. Lang 201 (2010): $53-78$.

Dinno, Khalid S. The Syriac Orthodox Christians in the Late Ottoman Period and Beyond: Crisis then Revival. Piscataway NJ: Gorgias Press, 2017.

Dum-Tragut, Jasmin. Armenian: Modern Eastern Armenian. Amsterdam: John Benjamins Publishing Co, 2009.

Fahmy, Ziad. Ordinary Egyptians: Creating the Modern Nation Through Popular Culture (Stanford, CA: Stanford University Press, 2011).

Glass, Dagmar \& Geoffrey Roper. "Arabischer Buch- und Zeitungsdruck in der Arabischen Welt / Arabic Book and Newspaper Printing in the Arab World," in Hanebutt-Benz et al., Sprachen des Nahen Ostens und die Druckrevolution, 177-226.

Goldstein-Sabbah, S.R., H.L. Murre-van den Berg, eds. Modernity, Minority, and the Public Sphere:Jews and Christians in the Middle East. Leiden Studies in Islam and Society 4, Leiden: Brill, 2016; Open Access; DoI: 10.1163/9789004323285).

Goldstein-Sabbah, Sasha. "Jewish Education in Baghdad: Communal Space vs. Public Space," in Goldstein-Sabbah, Murre-van den Berg, Modernity, Minority, and the Public Sphere, 96-120.

Graf, Georg. Geschichte der christlichen arabischen Literatur: Die Übersetzungen (vol. 1), Die Schrifsteller bis zur Mitte des 15. Jahrhunderts (vol. 2), Die Schriftsteller von der Mitte des 15. bis zum Ende des 19. Jahrhunderts (vol. 3-4). Studi e Testi 118, 133, 146, 147; Vatican City: Biblioteca Apostolica Vaticana, 1944 (1), 1947 (2), 1949 (3), 1951 (4).

Grand'Henry, Jacques. "Christian Middle Arabic." In Encyclopedia of Arabic Language and Linguistics, edited by Lutz Edzard, Rudolf de Jong (Consulted online on 28 January 2019; http://dx.doi.org/10.1163/1570-6699_eall_EALL_COM_0055. First published online: 2011).

Griffith, Sidney. "What does Mecca have to do with Urhōy? Syriac Christianity, Islamic Origins, and the Qurān." In Syriac Encounters: Papers from the Sixth North American Syriac Symposium, Duke University, 26-29 June 2011, edited by M. Doerfler, E. Fiano, K. Smith, 369-99. Peeters: Louvain, 2015. 
Gyllin, Roger. The Genesis of the Modern Bulgarian Literary Language. Ph.D. Uppsala University: Stockholm 1991.

Gzella, Holger. A Cultural History of Aramaic: From the Beginnings to the Advent of Islam. Leiden: Brill, 2015.

Hacikyan, Agop, Gabriel Basmajian, Edward S. Franchuk, Nourhan Ouzounian, eds. The Heritage of Armenian literature. Vol. 3: From the Eighteenth Century to Modern Times. Detroit: Wayne State University Press, 2005.

Halperin, Liora. Babel in Zion:Jews, Nationalism, and Language Diversity in Palestine, 1920-1948. Yale: YUP, 2015.

Harrak, Amir. Syriac and Garshuni Inscriptions of Iraq, vol. 1: Text; vol. 2: Plates. Recueil des inscriptions syriaques; Paris: de Boccard, 2010.

Hary, Benjamin. "Judeo-Arabic in its Sociolinguistic Setting." Israel Oriental Studies 15 (1995): 129-155.

Hary, Benjamin. “Judeo-Arabic: A Diachronic Reexamination." International Journal for the Sociology of Language 163 (2003): 61-76.

Hary, Benjamin \& Martin J. Wein. "Religiolinguistics: On Jewish-, Christian- and Muslim-defined Languages." International Journal of the Sociology of Language 220 (2013): 85-108.

Hastings, Adrian. The Construction of Nationhood: Ethnicity, Religion and Nationalism. Cambridge: Cambridge University Press, 1997.

Heyberger, Bernard. "Livres et pratiques de la lecture chez les Chrétiens (Syrie, Liban), $\mathrm{XVI}^{\mathrm{e}}-\mathrm{XVIII}{ }^{\mathrm{e}}$ siècles." In 'Livres et lecture dans le monde ottoman,' special issue edited by Frédéric Hirzel of REMMM 87/88 (2007), 209-23.

Holes, Clive. Modern Arabic: Structures, Functions, and Varieties, Rev. Edition. Washington D.C.: Georgetown University Press, 2004.

Hopwood, Derek. The Russian Presence in Syria and Palestine, 1843-1914: Church and Politics in the Near East. New York: Oxford University Press, 1969.

Hourani, Albert. Arabic Thought in the Liberal Age, 1798-1939. Cambridge, CuP, 1983/2014; ist ed. Oxford 1962.

Issa, Rana. "The Arabic Language and Syro-Lebanese National Identity: Searching in Buṭrus al-Bustānī's Muhịt al-Muhịt." Journal of Semitic Studies LXII/2 (2017):465-484. Joseph, John Earl. Language and Identity: National, Ethnic, Religious. Houndmills/New York: Palgrave Macmillan, 2004.

Jouse, P. "L'Origine des habitants orthodoxes de la Syrie et de la Palestine," Chronos: Revue d'Histoire de l'Université de Balamand, IV (2001), pp. 249-273. (First publication: Palestinskii Sbornik, XVII, fasc. 2 (1906), 161-182.

Kappler, Matthias. "The Place of the Grammatiki Tis Tourkikis Glossis (1730) by Kaneloos Spanós in Ottoman Greek Grammarianism and its Importance for Karamanlidika Studies." In Balta \& Ölmez, Cultural Encounters, $105^{-117 .}$ 
Kappler, Matthias. "Transcription Text, Regraphization, Variety? - Reflections on 'Karamanlidika'. In Spoken Ottoman in Mediator Texts, edited by Éva Á. Csató, Astrid Menz and Fikret Turan (Wiesbaden: Harrassowitz, 2016), 119-128.

Kaufman, Asher. Reviving Phoenicia: The Search for Identity in Lebanon. London, I.B. Tauris, 2004/2014.

Khalidi, Rashid, Lisa Anderson, Muhammad Muslih, Reeva S. Simon, eds. The Origins of Arab Nationalism. New York: Columbia University Press, 1991.

Khan, Geoffrey, "40, Northeastern Neo-Aramaic," in The Semitic Languages. Ed. Weninger, 708-724.

Kiraz, George A. Túrāṣ mamllā: A Grammar of the Syriac language. Volume 1: Orthography. Piscataway, NJ: Gorgias Press, 2012.

Leezenberg, Michiel. "Eli Teremaxi and the Vernacularization of Medrese Learning in Kurdistan." Iranian Studies 47 (2014): 713-733.

Leezenberg, Michiel. “The Vernacular Revolution: Reclaiming Early Modern Grammatical Traditions in the Ottoman Empire." History of Humanities (2016) 1,2: 251-275.

Lentin, J. \& J. Grand'Henry. Moyen arabe et variétés mixtes de l'arabe à travers l'histoire. Peeters: Louvain-la-Neuve, 2008.

Lewis, Geoffrey. The Turkish Language Reform: A Catastrophic Success. Oxford: Oxford University Press, 1999.

Mahmood, Saba. Religious Difference in a Secular Age: A Minority Report. Princeton/ Oxford: Princeton University Press, 2016.

Makdisi, Ussama. The Culture of Sectarianism Community, History, and Violence in Nineteenth-century Ottoman Lebanon. Berkeley, CA: University of California Press, 2000.

Makdisi, Ussama. Artillery of Heaven: American Missionaries and the Failed Conversion of the Middle East. Ithaca: Cornell University Press, 2008.

Mansour, Jacob. The Jewish Baghdadi dialect: studies and texts in the Judaeo-Arabic dialect of Baghdad. Or-Yehuda: The Babylonian Jewry Heritage Center, the Institute for Research on Iraqi Jewry, 1991.

Masters, Bruce. Christians andJews in the Ottoman Arab World:The Roots of Sectarianism. Cambridge: CUP, 2001.

Mengozzi, Alessandro. Israel of Alqosh and Joseph of Telkepe. A Story in a Truthful Language, Religious Poems in Vernacular Syriac (North Iraq, 17th century). Csco 589-590, Scr. Syr. 230-231; Louvain: Peeters 2002.

Mengozzi, Alessandro. Religious Poetry in Vernacular Syriac from Northern Iraq (17th2oth Centuries): An Anthology, Introduction and Translation. csco 627-628 / Scr. Syr. 240-241; Louvain: Peeters 2011.

Merguerian, Barbara J. "The ABCFM press and the development of the Western Armenian language," Harvard Library Bulletin 9.1 (1998): 35-49. 
Migliorino, Nicola. (Re)Constructing Armenia in Lebanon and Syria: Ethno-Cultural Diversity and the Sate in the Aftermath of a Refugee Crisis. New York: Berghan Books, 2008.

Moreen, Vera. In Queen Esther's Garden: An Anthology of Judeo-Persian Literature. New Haven/London: Yale University Press, 2000.

Mufti, Aamir R. "Secularism and Minority: Elements of a Critique." Social Text 45 (1995): 75-96.

Murre-van den Berg, Heleen. From a Spoken to a Written Language: The Introduction and Development of Literary Urmia Aramaic in the Nineteenth Century. De Goeje Fund XXVIII: Leiden, 1999.

Murre-van den Berg, Heleen. "Classical Syriac, Neo-Aramaic and Arabic in the Church of the East and the Chaldean Church between 1500 and 180o." In Aramaic in its Historical and Linguistic Setting, edited by Holger Gzella, Margaretha L. Folmer, 335-352. Veröffentlichungen der Orientalischen Kommission 50; Wiesbaden: Harrassowitz, 2008.

Murre-van den Berg, Heleen. "A Center of Transnational Syriac Orthodoxy: St. Mark's Convent in Jerusalem." Journal of Levantine Studies 3,1 (2013): 61-83.

Murre-van den Berg, Heleen. "Classical Syriac and the Syriac Churches: A Twentieth-Century History." In Syriac Encounters: Papers from the Sixth North American Syriac Symposium, Duke University, 26-29June 2011, edited by M. Doerfler, E. Fiano, K. Smith, 119-148. Peeters: Louvain, 2015.

Murre-van den Berg, Heleen. Scribes and Scriptures: The Church of the East in the Eastern Ottoman Provinces (1500-1850). Eastern Christian Studies 21; Louvain: Peeters, 2015. Murre-van den Berg, Heleen. "Searching for Common Ground: Jews and Christians in the Modern Middle East." In Modernity, Minority, and the Public Sphere: Jews and Christians in the Middle East, edited by S.R. Goldstein-Sabbah, H.L. Murre-van den Berg (Leiden: Brill, 2016), 3-38 (Open Access: DoI 10.1163/9789004323285_002).

Murre-van den Berg, Heleen. "The Language of the Nation: The Rise of Arabic among Jews and Christians (1900-1950)," British Journal of Middle Eastern Studies 43(2) (2016): 176-190.

al-Musawi, Muhsin J. The Medieval Islamic Republic of Letters: Arabic Knowledge Construction. Notre Dame, Indiana: University of Notre Dame Press, 2015.

Myhill, John. Language, Religion and National Identity in Europe and the Middle East. Amsterdam:John Benjamins, 2006.

Neudecker, Hannah. The Turkish Bible Translation by Yahya bin 'Isḥak, also called Haki (1659). Leiden: Het Oosters Instituut 4, 1994.

Nichanian, Marc. Ages et usages de la langue arménienne. Geneva: Éditions Entente, 1989. Omoniyi, Tope, Joshua A. Fishman, eds. Explorations in the Sociology of Language and Religion. Amsterdam: John Benjamins, 2006. 
Panchenko, Constantin A. Arab Orthodox Christians under the Ottomans: 1516-1831. Jordanville NY: Holy Trinity Seminary Press, 2016; tr. Russian, Moscow 2012.

Papastathis, Konstantinos. "Religious Politics in Mandate Palestine: The Christian Orthodox Community Controversy in the Thirties." British Journal of Middle Eastern Studies 43,3 (2016): 259-284.

Pehlivanian, Méline. "Mesrops Erben: die Armenischen Buchdrucker der Frühzeit / Mesrop's Heir's:The early Armenian Book Printers," in Eva Hanebutt-Benz, Dagmar Glass, Geoffrey Roper, Sprachen des Nahen Ostens und die Druckrevolution: Eine interkulturelle Begegnung / Middle Eastern Languages and the Print Revolution: A Cross-cultural Encounter (Westhofen: WVA-Verlag Skulima, 2002), 53-92.

Pollock, Sheldon. The Language of the Gods in the World of Men: Sanskrit, Culture, and Power in Premodern India. Berkeley: UCP, 2006.

Rabbath, Edmond. Unité Syrienne et devenier arabe. Paris: Marcel Rivière, 1937.

Roper, Geoffrey. "The beginnings of Arabic printing by the ABCFM, 1822-1841," Harvard Library Bulletin 9.1 (1998): 50-68.

Roper, Geoffrey. Sprachen des Nahen Ostens und die Druckrevolution, 129-150.

Rumelili, Bahar \& Fuat Keyman. "Enacting multi-layered citizenship: Turkey's Armenians' struggle for justice and equality," Citizenship Studies 20,1 (2016): 67-83.

Sabar, Yona. The Five Scrolls in Jewish Neo-Aramaic Translations: Dialects of 'Amidya, Dihok, and Urmiya. A Critical Edition Based on Recordings and Manuscripts, Comparisons with Old Aramaic Bible Translations, Commentaries and Midrashim. 'Ẽāh w-lāšon: Jerusalem, Magnus Press, 2006.

Sabar, Yona. Jewish Neo-Aramaic Translations of Hebrew Liturgical Poems: A Critical Edition. 'E $\bar{d} \bar{a} h$ w-lāšon: Jerusalem, Magnus Press, 2009.

Salameh, Franck. Language, Memory, and Identity in the Middle East: The Case for Lebanon. Lanham, MD: Lexington Books, 2010.

Sanchez, Karène. "Linguistic diversity and ideologies among the Catholic minority in Mandate Palestine. Fear of confusion or powerful tool?." British Journal of Middle Eastern Studies 43,2 (2016): 191-205.

Sanchez, Karène. "Preserving Catholics of the Holy Land or integrating them into the Palestine nation? Catholic communities, language, identity and public space in Jerusalem (1920-1950)." In Goldstein-Sabbah, Modernity, Minority, and the Public Sphere, $121-151$.

Shachmon, Ori. "Halabi Arabic as a Contact Dialect in Jerusalem." Journal of Jewish Languages 5 (2017): 49-80.

Sheehi, Stephen. Foundations of Modern Arab Identity. Gainesville: University Press of Florida, 2004.

Sheehi, Stephen. "Towards a Critical Epistemology of the Nahda." Journal of Arabic Literature 43 (2012): 269-298. 
Sheehi, Stephen. "Butrus al-Bustani's Nafir Suriya and the National Subject as Effect." In Butrus al-Bustani: Spirit of the Age, edited by Adel Beshara, 275-309. Melbourne: Phoenix Publishing 2014.

Şişmanoğ-lu Şimşek, Şehnaz. "The Anatoli Newspaper and the Heyday of the Karamanli Press." In Balta \& Kappler, Cries and Whispers, 109-123.

Strauss, Johann. "Who Read What in the Ottoman Empire (19th-2oth Centuries)?," Arabic Middle Eastern Literatures 6,1 (2003): 39-76.

Strauss, Johann. "Is Karamanli Literature Part of a 'Christian-Turkish (Turco-Christian) Literature'?," in Balta \& Kappler, Cries and Whispers, 152-200.

Suleiman, Yasir. The Arabic Language and National Identity. Georgetown University Press, Washington DC, 2003.

Suleiman, Yasir. "Charting the Nation: Arabic and the Politics of Identity." Annual Review of Applied Linguistics (2006) 26: 125-148.

Suleiman, Yasir. A War of Worlds: Language and Conflict in the Middle East. Cambridge: Cambridge University Press, 2004.

Suleiman, Yasir. Arabic in the Fray: Language Ideology and Cultural Politics. Edinburgh: Edinburgh University Press, 2013.

Taşğın, Ahmet and Robert Langer. "The Establishment of the Syrian Orthodox Patriarchate Press." In Historical Aspects of Printing and Publishing in Languages of the Middle East. Papers from the Third Symposium on the History of Printing and Publishing in the Languages and Countries of the Middle East, University of Leipzig, September 2008, edited by Geoffrey Roper (Leiden/Boston: Brill 2014), 181-192.

Taylor, Charles. A Secular Age. Cambridge: Harvard University Press, 2007.

Teule, Herman \& Vic Schepens. "A Thematic Christian Arabic Bibliography, 1940-1989," Journal of Eastern Christian Studies (2015) 67-1/2, 143-224.

Theocharides, Ioannis. "Unexploited Sources on Serapheim Pissidio." In Balta \& Kappler, Cries and Whispers, 125-134.

Trigona-Harany, Benjamin. "A Bibliography of Süryânî Periodicals in Ottoman Turkish," Hugoye:Journal of Syriac Studies 12.2 (2009): 287-300.

Trigona-Harany, Benjamin. "Syro-Ottoman: a description of Ottoman Turkish in Syriac Letters." In Balta \& Ölmez, Between Religion and Language (2011), 15-41.

Trigona-Harany, Benjamin. The Ottoman Süryânî from 1908 to 1914. Piscataway NJ: Gorgias Press, 2009.

Ueno, Masayuki. "One script, two languages: Garabed Panosian and his Armeno-Turkish newspapers in the nineteenth-century Ottoman Empire." Middle Eastern Studies 52:4 (2016): 605-622.

Versteegh, Kees. The Arabic Language. Edinburgh: Edinburgh University press 1997/2014.

Versteegh, Kees. "Religion as a Linguistic Variable in Christian Greek, Latin, and Arabic." In Philologists in the World: A Festschrift in Honour of Gunvor Mejdell, edited by Nora S. Eggen and Rana Issa, 57-99. Oslo: Novus Press, 2017. 
Vial, Theodore. Modern Religion, Modern Race. Oxford, oup, 2016.

Vovchenko, Denis. "Creating Arab Nationalism? Russia and Greece in Ottoman Syria and Palestine (1840-1909)." Middle Eastern Studies 49 (2013): 901-918.

Vovchenko, Denis. Containing Balkan Nationalism: Imperial Russia and Ottoman Christians, 1856-1914. Oxford: Oxford University Press, 2016.

Walbiner, Carsten. "Monastic Reading and Learning in Eighteenth-Century Bilad al-Sham: some evidence from the monastery of Al-Shawayr (Mount Lebanon)." Arabica 6,4 (2004): 462-77.

Wallach, Yair. "Creating a Country through Currency and Stamps: State Symbols and Nation-building in British-ruled Palestine." Nations and Nationalism 17,1 (2011): 129-147.

Watenpaugh, Keith David. Being Modern in the Middle East. Revolution, Nationalism, Colonialism and the Arab Middle Class. Princeton: Princeton University Press, 2006.

Weninger, Stefan, ed. The Semitic Languages: An International Handbook. Berlin: De Gruyter Mouton, 2011.

White, Benjamin Thomas. The Emergence of Minorities in the Middle East: The Politics of Community in French Mandate Syria. Edinburgh: Edinburgh University Press, 2011.

Wien, Peter. Iraqi Arab Nationalism: Authoritarian, Totalitarian, and pro-fascist Inclinations, 1932-1941. Abingdon/New York: Routledge, 2006.

Wolf, Hans-Georg. "British and French language and educational policies in the Mandate and Trusteeship Territories." Language Sciences 30.5 (2008): 553-574.

Woolard, Kathryn A., Bambi B. Schieffelin. "Language Ideology," Annu.Rev.Anthropol. 23 (1994): 55-82.

Yousef, Hoda A. Composing Egypt: Reading, Writing, and the Emergence of a Modern Nation, 1870-1930. Stanford CA: Stanford University Press, 2016.

Zander, Walter. Israel and the Holy Places of Christendom. London: Weidenfeld and Nicholson: 1971. 